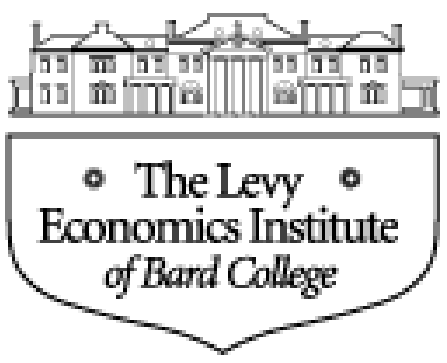

Working Paper No. 452

\title{
The Minskyan System, Part I \\ Properties of the Minskyan Analysis and How to Theorize and Model a Monetary Production Economy
}

By

Eric Tymoigne

UMKC - Department of Economics

June 2006

The Levy Economics Institute Working Paper Collection presents research in progress by

Levy Institute scholars and conference participants. The purpose of the series is to disseminate ideas to and elicit comments from academics and professionals.

The Levy Economics Institute of Bard College, founded in 1986, is a nonprofit, nonpartisan, independently funded research organization devoted to public service. Through scholarship and economic research it generates viable, effective public policy responses to important economic problems that profoundly affect the quality of life in the United States and abroad.

The Levy Economics Institute P.O. Box 5000

Annandale-on-Hudson, NY 12504-5000

http://www.levy.org

Copyright (C) The Levy Economics Institute 2006 All rights reserved. 


\begin{abstract}
This is the first part of a three-part analysis of the Minskyan framework. Via an extensive review of the literature, this paper looks at 12 essential elements necessary to get a good understanding of Minsky's theory, and argues that those elements are central to comprehend how a monetary production economy works. This paper also shows how important these 12 elements are for the modeling of the Minskyan framework, and how the omission of one of them may be detrimental to an understanding of the essential dynamics that Minsky put forward: the Financial Instability Hypothesis.
\end{abstract}

JEL classifications: E5

Keywords: Post-Keynesian economics, Minsky, financial fragility 
Some authors have argued that Minsky's theory rests on irrational behaviors and euphoria (Bernanke 1983; Mullineux 1990; Benston and Kaufman 1995), on the loanable funds theory or on fallacies of composition (Lavoie 1983, 1986, 1996, 1997; Brossard 1998, 2001; Lavoie and Seccarecia 2001; Parguez 2003; Rochon 2003b), on a reserve-multiplier process (Rochon 2003a), or that asymmetric information is essential for the analysis (Fazzari 1992). Less friendly authors have simply stated that Minsky's theory is "noninformative", "obscure", "vague", or, more colorfully, full of "empty boxes", "which he filled with carrots, chickens, eggs, milk, cream, and the like" (Meiselman 1967) or even the work of a "beast", as Minsky called himself (Minsky 1984a). Therefore, some clarifications seem necessary, not about what Minsky "really meant" but, more basically, about the way his theory developed and about the cause of financial instability. The following is the first part of a study of the Minskyan framework. It shows that the main “organizing principles" (Minsky 1986a) of Minsky's theory can be regrouped in twelve different points, going from the nature of capitalism to the role of authorities in the management of the economic system. Ultimately, a good modeling of the Minskyan framework requires these twelve principles. The second part of the study will examine, in detail, the dynamics implied by the financial instability hypothesis, and the third part will provide a modeling of Minsky's theory.

\section{THE NATURE OF THE CAPITALIST SYSTEM: A MONETARY PRODUCTION ECONOMY}

Minsky's center of attention is the capitalist economic system (Ferri and Minsky 1989). As he recognized, there are different forms of capitalist system (Minsky 1989a, 1990a, 1990b, 1993a; Whalen 1997; Papadimitriou and Wray 1997) but all these forms have similar characteristics:

A capitalist economy [...] [is] an integrate production, trading, and wealth owning system, with a structure of financial claims and commitments, [that] operates through real world and irreversible time. (Minsky 1983b)

This definition shows that a capitalist economy is, first, a monetary production economy. It is a monetary economy, not because money is used, but because money is at the center of economic decisions, both at the beginning and at the end of the economic process. "Only that which is 
financed can happen" (Minsky 1990a), and the aim of any economic activity is to make a net monetary gain. This implies that, as shown later, in a monetary production economy, nominal values matter more than real values and the main aim is to stay liquid and solvent. Another implication is that the financial frame is an essential part of the system and that, as shown later, it is a central cause of flexibility and instability for the capitalist economic system. Second, the above definition shows that competition is an essential ingredient of capitalism to take into account in order to understand its dynamics (Goldstein 1995). The agents involved in this economic system are always trying to guess the uncertain future in order to obtain a bigger monetary profit than their competitors. This race toward the future is at the source of the productivity of the capitalist system, but also at the source of its instability. In addition, competition is an essential ingredient in the formation of conventions and their wide use by economic agents as anchors for economic decisions. As Wojnilower notes about bankers:

In the 1960s, commercial bank clients frequently inquired how far they could prudently go in breaching traditional standards of liquidity and capitalization that were clearly obsolescent. My advice was always the same - to stick with the majority. Anyone out front risked drawing the lightning of the Federal Reserve or other regulatory retribution. Anyone who lagged behind would lose their market share. But those in the middle had safety in numbers; they could not all be punished, for fear of the repercussion of the economy as a whole. [...] And if the problem grew too big for the Federal Reserve and the banking system were swamped, well then the world would be at an end anyhow and even the most cautious of banks would likely be dragged down with the rest. (Wojnilower 1977)

Finally, the future is uncertain and time is not reversible. This is, again, a source of both dynamism and instability because, as Keynes remarked, if investment depended on "nothing but a mathematical expectation, enterprise [would] fade and die" (Keynes 1936). Uncertainty leaves the future opened to the imagination of entrepreneurs.

There is, therefore, a constant dialectic in Minsky's theory that reflects the "constitutional" or "inherent" flaw of the financial structure — the need to make position that emerges from the normal functioning of the capitalist system. In a complex financial system, this need may lead, in addition to financial fragility, to inflation, unemployment, and rise in inequality (Minsky 1986a). This flaw is related to the existence of capital assets, a fundamental source of uncertainty (Keynes 1936), but more precisely and deeply, rests on the financing and funding process of capital equipment (Minsky 1975a). Indeed, because the latter is very 
expensive and has a long gestation period determined by its construction, installment, and testing periods (Minsky 1977c, 1986a), and because the financing of their production and the funding of their acquisition are usually provided with a maturity term shorter than its gestation period, there is a maturity mismatch between assets and liabilities on the balance sheet of both enterprises and banks. This creates a need to make position that is at the origins of "the emergence of financial relations that can lead to snowballing instability" (Fazzari and Minsky 1984).

One important point to note, however, is that that this financial mismatch does not concern only capital assets production and acquisition; it concerns all kinds of economic activities from consumption to speculation on financial assets. Even if the dependence on investment were greatly reduced, this would not do the trick if consumption started to be financed and funded in the same way. Thus, the fundamental flaw of the capitalist system really lies in the banking and financial system, not in the entrepreneurial system. Isenberg $(1988,1994)$ and Stanfield and Phillips (1991) assume that "the problem of instability is rooted in the nature of capitalist commodity production" (Stanfield and Phillips 1991), but this is a narrow view of Minsky's theory.

Another important point is that the flaw is not related directly to the uncertainty of the future and so the non-realization of expectations, an inherent "flaw" of all economic systems, but to the way economic activity is financed and funded. Stated alternatively, there is no need for an unrealistic and overly optimistic state of expectations to generate financial fragility and instability. All that is required is a mismatch in the maturity of the asset and liability sides of balance sheets, and a conventional basis of decision about the appropriate financing and funding method that becomes looser, combined with a lack of understanding of macroeconomic mechanisms, so that in the end expectations are frustrated.

A modeling of the Minskyan framework required, therefore, a model constructed in nominal terms in which the financing and the funding of all economic activities, productive or not (that is, leading or not leading to an increase in national income), are explicitly stated for all economic sectors. Taking into account the non-productive financial activities that emerge from the normal financing and funding of productive activities is central to the Minskyan system. 


\section{AGENTS ARE RATIONAL: OVER-OPTIMISM, CONVENTION AND NORMAL/ACCEPTABLE MARGINS OF SAFETY}

In Minsky's theoretical framework, the Wall-Street view, agents make arbitrages between all assets (productive and financial) as a function of their expected rate of return from income and capital gains (Minsky 1972a, 1975a, 1986a). The "fundamental speculative decision" is, then, to decide which assets to acquire and how to fund the position in those assets (Minsky 1975a).

Because of the nature of the system that Minsky studies, decisions are based on conventional judgments. This kind of behavior is rational (Minsky 1989c, 1993b; Goldstein 1995; Crotty 1994). Indeed, in order to make any decision, individuals construct mental explanations (or "models") of how they think the economic system works and will work in the future. They know, however, that these explanations do not replicate the "true" model of the economic system, but are just representations that have been commonly agreed upon by members of the economy or a specific sector of the economy. Therefore, economic agents know that they can be systematically wrong. These errors are not based on the existence of asymmetric information, or bounded rationality, but on the uncertainty of the economic system (Dunn 2001) - the future is unknowable. Asymmetries of information can be added to the explanation but they are not essential to understand the behavior of entrepreneurs and bankers (Minsky 1989a, 1993b; Dymski 1994).

Conventions, therefore, play a central role in Minsky's analysis. In normal time, there is always a "consensus" (Minsky 1972a) that exists and stabilizes the decision-making process by playing the role of "certainty equivalent" (Minsky 1975a). Those conventions do not need to rest on any objective criteria, but may rest on the "prevailing mood of bankers, the users of their liabilities, and the regulatory authorities as to the safety of various types of assets" and methods of financing and funding (Minsky 1975b). These conventions are, then, used to determine the acceptable criteria that borrowers must meet in order to be granted loans. As shown below, in this process of selection, both the initiator of a project and the lender are actively involved. There is no a priori supposition that bankers are in an inferior position.

In the modeling process, the prevailing convention about how the economic system works determines the state of long-term expectations - that is, the expected profitability and liquidity of capital assets. This state of expectations is used to determine the level of economic 
activity, as well as the normal margins of safety used when economic activities need to be externally funded (Minsky 1975a). The causality runs as follows:

\section{Convention $\rightarrow$ State of expectations $\rightarrow$ Normal margins of safety}

One of the central points of the modeling is, thus, to specify how the conventions, and so the normal margins of safety, change over time:

The fundamental instability is the way in which a period of steady growth evolves into a speculative boom. Central to this evolution is the endogenous determination of accepted or desired liability structure of not only ordinary business firms (corporations) but also banks. (Minsky 1974)

In Minsky's framework, the normal margins of safety always loosen during a period of prolonged growth as the convention sustaining these margins seems to represent well what is going on, or as unexpected events can be explained by the convention. This reflects a change in the state of expectation that represents a higher confidence in a given set of expected monetary cash flows; borrower's and lender's risk loosen given expected gross inflows $(E(\Pi)$ if one takes the firm sector). Economic actors become more "daring" (Minsky 1975a). At the same time, $E(\Pi)$ may itself be revised upward and, ultimately, the possibility of failure (negative or too low П) may become progressively unconceivable. ${ }^{1}$ This may lead to euphoria, or "over-optimism", and Minsky explicitly took this definition for "euphoria" - "gross profits in the present-value calculations that had reflected expected recessions are replaced by those that reflect continuing expansion. Simultaneously there is less uncertainty about the future behavior of the economy." (Minsky 1972b). Stated alternatively, a euphoric period assumed that cycles are a "thing of the past" (Minsky 1975a) and the confidence in the explanation sustaining this belief (the "new era" convention) is high.

However, it is important to understand that euphoria is not necessary to explain why the acceptable margins of safety loosen. Indeed, the notion of "over" implies that there is an explicit a priori norm of judgment where, in fact, there is none. All that is necessary to explain the

\footnotetext{
${ }^{1}$ More formally, for the firm sector, we have: $Q \equiv E(\Pi)+/-\theta \sigma_{\Pi}$, with the boundary $Q \equiv E(\Pi)-\theta \sigma_{\Pi}$ being of central importance. Both $\Delta E(\Pi)>0$ and $\Delta \theta<0$ lead to $\Delta Q>0$, but via different channels.
} 
loosening of normal margins of safety is an understanding of the dynamics of conventions over time. Prolonged expansion means a history of successes, and so more favorable data inputted in the decision process, as well as a common agreement among the economic community about the "most profitable" and "less risky" projects (Kregel 1997).

As we learn from the past and as horizons are short, a run of success or failure will feed back quickly into the evaluation of risks. (Minsky 1967a)

The determination of the cash to be expected by the borrower depends upon the loan officer's views of what business conditions over the time of the contract will be; these views, even in an era where loan officers use forecasts of the economy, are seriously affected by the performance on outstanding loans. (Minsky 1984b)

Stated alternatively, a convention puts in place a potential positive feedback loop in terms of state of expectations and so acceptable margins of safety. This is due to the psychological factors that enter in the decision process of any human being: heuristics, tendency to discount the past, etc. (Kahneman and Tversky 1973; Tversky and Kahneman 1974; Shiller 1999; Harvey 1998). Euphoria cannot explain the progressive weakening of the economy because "the euphoric period has a short lifespan" (Minsky 1972b). Therefore, "over-optimism" may only enter late into the analysis and only helps to precipitate the turning point of a business cycle. As Taylor, O'Connel, Franke, and Semmler note, bubbles are not central to explain how a crisis emerges in Minsky's framework (Taylor and O'Connell 1985; Frank and Semmler 1989).

A third element, not quite so basic, that determines vulnerability to a financial crisis is the extent to which expectations of growth and of rising asset prices have affected current assets prices. (Minsky 1972b, italics added)

The essential conclusion is that higher $Q$ and higher leveraging of $Q$ are important points of the theory to consider - these are automatic trends in a prolonged expansion that are not generated by over-optimism or euphoria. 


\section{FINANCIAL INNOVATIONS}

The dialectic of capitalism also emerges at the level of financial innovations because the latter play an essential role in the long-term financial weakening of the financial system, but they also improve the flexibility of the capitalist system.

Financial innovations are driven by competitive pressures to make profit (Minsky 1957a, 1969a, 1986a) and are first experimented with by giant banks and enterprises and then diffused to the rest of the economy (Minsky 1983a). Indeed, bankers and entrepreneurs are profit-seeking agents, so they always try to innovate financially in order to bypass the barrier imposed on them by the regulatory and natural systems, or to adapt the financing and funding process to the needs of the different economic activities - both financial and technological innovations are at the root of the dynamism of the capitalist economic system. In this sense, financial innovations are a welcome counterpart to productive innovations (Minsky 1969a) and should be promoted by regulatory authorities (Minsky 1967b, 1969b, 1972b).

One essential difference between technological innovations and financial innovations is that the latter has no natural limit.

The rate of increase of financial variables is limited only by ingenuity and acceptability. In a world with layering, the rate of change of financial variables really has no bounds. The ability of financial layering to increase the burden on the payments mechanism is one way in which the conditions necessary for financial instability can be generated. (Minsky 1967a)

This unlimited a priori constraint on financial innovations is a potential source of instability (Minsky 1984a). Indeed, the increase in the layering of IOUs leads to an increasing interdependence of economic agents for their money inflows and money outflows, and so an increasing dependence on economic conditions upon which they do not have any control (default(s) of other economic agents, increase in interest rates and other changes that affect cash flows). This layering process, therefore, needs to be explained. The essential conclusion, for the moment, is that a modeling of Minsky's should be able to include financial innovations, and to look at their impact on the economic system. Indeed, they play an essential role in the growth of the economy and its financial weakening. 


\section{PYRAMID OF IOUs: LAYERING, MONETARY CREATION AND VALUE OF IOUs}

In 1972, Minsky contended that: "Any economic unit can emit liabilities; the only problem is to secure general acceptance for them" (Minsky 1972c). This statement may seem strange but this is what happens all the time in a capitalist economy. Banks and other financial institutions accept IOUs of private non-banks agents in exchange of their own IOUs that are transferable means of payments (they are money-things). This transferability, or payment capacity, is hierarchically determined with the central bank liabilities at the top (Minsky 1967b, 1985; Innes 1914; Bell 2001).

As the process of growth expends, "a hierarchy of liquid assets comes into being" (Minsky 1986a) and so there is a deepening in the layering of financial relationships. This is, of course, related to the innovation process that was discussed earlier.

\subsection{Leveraging, the Acceptance of Liability, and the Crucial Role of the Reflux}

The ability of banks to increase their assets "depends on the supply of acceptable assets from business, other financial institutions, government, and households" (Minsky 1975b). The acceptance by banks of the IOUs of non-bank private agents rests on the expected capacity of the latter to "acquire credits", i.e., "to force cash flows", from others (Innes 1913; Minsky 1986a). Indeed, the creation of IOUs (and so money-things) is a leveraging process that provides money now for money later (Keynes 1936; Minsky 1977b). The lower the expected reflux, the harder the lending conditions are for the issuers concerned.

The actual capacity to acquire credits determines the value of IOUs. Indeed, moneythings are debts, therefore, they must be able to reflux when required so that the relative scarcity of money-things is preserved. For banks, the scarcity of their IOUs depends on their capacity to fulfill their promise and to deliver central-bank IOUs. For central bank IOUs and Treasury, their value depends on the capacity of the government to collect the taxes, or other obligations, it previously imposed. Therefore, in total, the value of money "is maintained by the need to make payments to banks and Treasury by debtors and taxpayers" (Minsky 1986c). Putting together the acceptance and value of bank IOUs, Minsky concluded: 
Why is 'bank money' accepted? [...] the answer comes in two steps: any bank dollar is convertible at par into any other bank dollar, and a significant set of units are committed to earn bank dollars in order to fulfill their obligations on debts that are owned by banks. Bank dollars are valuable because units are operating in the economy to get bank dollars so they can pay bank debt and in the process destroy bank dollars. (Minsky 1985)

The role of the reflux mechanism is, therefore, very important and directly related to the weakening process of the financial structure - IOUs must be able to come back to their issuers when needed. If there is no reflux, there is a refinancing process that leads, at the macroeconomic level, to inflation or, at the international level, to a depreciation of the currency (Minsky 1979, 1986b). Speculative and Ponzi financial structures are, thus, prone to inflationary pressure because the reflux is either partial or nil.

\subsection{Exogenous Money, Endogenous Money and Financial Innovations}

Questions about the endogeneity of the money supply were not really developed in Minsky's approach before the mid-1960s. These questions became more present with the emergence of Monetarism. In 1967, he started to criticize the idea that a central bank can control the amount of its IOUs in circulation:

It cannot be assumed that the amount and the rate of change of reserve money is either exogenously determined or the result of a policy decision. (Minsky 1967a)

Later, he constantly repeated that the supply of financial instruments changes with the financial needs of the economic system (Minsky 1977b, 1984a, 1985).

In this context, "leveraging" does not mean "multiplying" on borrowed funds, it means "promising to pay/deliver". An agent who creates an IOU today leverages his/her position because, today, $\mathrm{s} / \mathrm{he}$ is short in the thing $\mathrm{s} / \mathrm{he}$ promises to deliver. In this sense:

A bank is not a money lender that first acquires and then places funds. [...] a bank first lends or invests and then 'finds' the cash to cover whatever cash drains arise. (Minsky 1975c)

Therefore, the monetary creation process has no technical limit like a multiplier. A shortage of reserves does not lead to a cut in lending unless getting them is harmful for the profitability and 
solvency of banks (Minsky 1986a). Indeed, the capability of the latter to get funds at a relatively cheap price will define the profitability limit of the issuance of bank IOUs. Financial innovation, then, may be a way to postpone this profitability limit by allowing a refinancing of reserve positions at low interest rate, relative to the interest rate obtained from accepting non-bank IOUs (i.e., providing bank loans). Financial innovations are, thus, not a cause ${ }^{2}$ of endogeneity of money (which it is by nature), but a way to increase the profitability of monetary creation there is a "financial innovation barrier" (Minsky 1986a). Only profitability and conventions determine the structure of the balance sheets of banks (Minsky 1979).

That bank money is endogenous (i.e., cannot be created if there is no demand for it) and does not preclude that part of the central-bank money (reserves) are supplied exogenously by the spending of the Treasury (i.e., independently of the demand for reserves by banks): "the money supply is in part endogenous and in part exogenous" (Minsky 1991a). Contrary to Moore (1996) or Chick (1986), however, this is not due to historical or institutional characteristics but to different procedures of injection of IOUs between the private and the public sector. Bank IOUs are created at the initiative of needs of creditworthy economic agents, whereas the Treasury may "force" the public to accept its IOUs by imposing a debt (usually a tax liability). This latter supply of reserves is vertical even though the government may have to pay interest on them to keep overnight rates above zero (Wray 1998), and this "second meaning of exogeneity requires that profit seeking activity be removed from financial markets and institutions" (Minsky 1991a).

\section{THE ROLE OF BANKERS}

As stated earlier, asymmetry of information is not essential in the Minskyan approach, so the theory does not depend on "borrowers being smart and bankers being dumb" (Minsky 1993b). On the contrary, bankers are an essential component of the system at all stages of the economic

\footnotetext{
${ }^{2}$ This may not always be clear in Minsky's writing, especially his early writing (e.g. Minsky 1957a, 1975a), but this distinction between endogeneity of money and profitability of money creation (and so financial innovations) is present from the very beginning of is work. For example, Minsky (1957a) clearly shows how financial innovations allow to increase the velocity of money (i.e. the circulation of a given amount of money) without generating any changes in interest rates.
} 
process. In addition, bankers are both a source of dynamism and destabilization and, therefore, they need to be managed (Minsky 1980b).

Minsky is famous for generalizing the term "banks" to all kinds of institutions that contribute, directly and indirectly, to the financing and funding of economic activities. Sometimes, he differentiates between "fringe banking" and "banking proper".

Banking is used as a generic label for the various classes of dealers (position-takers) and brokers that intermediate and facilitate financing. Banking proper-i.e., organizations which have deposit subject to check among their liabilities - are referred to as either commercial or deposit banking. (Minsky 1984a)

This allowed him to go more in detail in the layers of the pyramid containing bank IOUs: "Fringe bank" IOUs (including non-financial institutions IOUs like commercial papers) are leveraged upon "proper" bank IOUs (depository institutions deposits) (Minsky 1975c, 1975d). Therefore, the main difference between depository institutions and other financial institutions is that, at least before 1980 in the United States with the DIDMCA, only the former have direct access to central-bank refinancing so that depository institutions deposits can be counted as part of the money "properly defined" (Minsky 1967a). The other financial institutions have to leverage their positions on commercial banks or other depository institutions; they do not have access to central-bank refinancing, and commercial banks may refuse to refinance or may refinance only at a large discount. However, depository institutions are not, by nature, different from any other financial institutions - they all leverage central-bank IOUs, either directly or indirectly. In addition, they all obtain their incomes in the same way: "Arranging financing" (fees), "making on the carry of a fund they manage" (interest-rate differential), and "selling their services in making payments over distance and time" (interest rate, fees) (Minsky 1986a).

Banks are at the heart of the capitalist system and may promote both stability and instability due to their structural organization. In banks, there are two essential "operators" (Minsky 1984b) or "desks" - the loan officer desk and the position-making desk.

The central role of the banking system is to evaluate the creditworthiness of borrowers (Minsky 1986a): 
Bankers are 'specialists' in 'determining' the likelihood of success of moneymaking business schemes that require external finance. (Minsky 1984b)

Loan officers of banks are professionals, skilled in the evaluation of privately submitted and often confidential information about the operations of businesses, households, and government units that require financing. (Minsky 1994)

Therefore, the loan officer is central and Minsky deplored the fact that money-market funds are "banks without a loan officer" (Minsky 1981). Underwriters and analysts play the role of loan officer in a market-oriented financing but there is no long-term and continuous relationship between clients and their bankers (Minsky 1994). This makes analysts and underwriters more prone to optimism, and detaches bankers from the reality of the economic activity of their customers. ${ }^{3}$ Indeed, loans officers represent the conservative face of a bank and examine each project presented to them in great detail to "transform optimistic expectations in realist expectations" (Minsky 1994); they are the "designated skeptic" (Minsky 1994) in the game of guessing the future and, therefore, restrain the potential fragility of the economy (Minsky 1986a; Kregel 1997). ${ }^{4}$ Loan officers are, thus, essential for the stability of the capitalist system, even if their skepticism may be eroded by a period of prolonged expansion.

This operator of banks is, however, completed by its opposite. Indeed, bankers "are skeptics as 'underwriters' and enthusiasts as 'sellers"' (Minsky 1996), that is, they assume that they will always be able to refinance their positions easily at a cost low enough not to comprise the profitability of granting loans, or that they will be able to pass the refinancing cost on their cash-inflow generating activities (increase in interest rate, fees, and other sources of funds). Banks are a "profit maximizing, highly levered, speculative enterprise" (Minsky 1975b) because the maturity of their debts is far shorter than the maturity of their assets so there is a refinancing cost upon which they have to "speculate" (Minsky 1977a). Furthermore, in addition to being intrinsic speculative units, banks promote speculative and Ponzi "financing." This is so for two reasons. First, the term to maturity of their assets (i.e., the maturity of the loans they are granted) is usually shorter than the maturity of the assets financed/funded (Minsky 1977a), and, second, in

\footnotetext{
${ }^{3}$ Shiller (2000) provides some examples that verify this preoccupation.

4 Therefore, another way to define "euphoria" is when loan officers start to believe that recessions are things of the past, that is, when they fail to correct overwhelmingly optimistic expectations.
} 
order to gain market shares, they have an incentive to encourage other units to substitute shortterm debts for long-term debts (Minsky 1982a). Thus:

Not only do banks engage in speculative finance, but also they are the transmission belt toward speculative financing by others. (Minsky 1977a)

In the end, the banking system is again a good representation of the dialectic that Minsky finds in the capitalist economic system; banks may promote the implementation of less risky projects, but they will also promote a short-term financing and funding of these projects. Thus, in the modeling process, it is important not only to show how bankers put a limit on the financial weakening of the system, but also to take into account maturity considerations - the maturity of loans has to be set lower than the maturity of the assets externally funded. Then, as long as there is a simple need to recontract a debt, there is a dependence on market conditions.

\section{THE COST OF EXTERNAL FUNDS}

One important point for the modeling of the Minsky's theory is to take into account the total cost of external funds. Indeed, in the expansionary phase, the change in the relationship between the amount of cash outflows and the amount of cash inflows is essential for the Financial Instability Hypothesis.

In the most abstract terms, the carrying cost of assets is what should be used to determine the cost of buying and holding assets (Minsky 1975a). This includes both the financial cost and "wastage" in the general sense of the terms (including depreciation, unexpected destruction, etc.). To simplify, only the financial cost is taken into account, but this still includes debt services, rental service for storage, insurance cost, as well as all other cash outflows generated by financial contracts. To simplify even more, only the interest payment of the debt service can be analyzed, but, as Minsky recognized, this is not a good approximation of the financial cost when debts are short-term debts because the amortization of the principal becomes important (Caskey and Fazzari 1986). 
In fact, if the financial contracts are sufficiently short, then the cash payments on financial contracts can exceed the total quasi rents. (Minsky 1975a)

Minsky was very careful to say that the interest rate is only a "shorthand" description of the cost of external funds and that what really matter are the terms of the financial contracts, including the maturity term and "various protections desired by producers and lenders" (Minsky 1980a). An increase in the cost of external funds is, thus, represented by higher interest rates, lower maturity term, and a requirement for more covenants and codicils (Minsky 1986a). In addition, there is an indirect cost induced by the increase in interest rates - the value of collateral decreases and so this may put an additional pressure on the cost of external funds. Thus, changes in the cost of external funds have stock and flow effects that contribute to the financial weakening of the economy in several ways (Minsky 1977b).

Therefore, a modeling of Minsky's theory cannot be based only on interest payments. At minimum, one should include the amortization rate because one essential aspect of the financialweakening process is that the financing and funding processes have a tendency to become shorter as the expansion goes. Thus, the increase in the cash commitments may not be due at all to an increase in interest rates; for a given amount borrowed, an increase in the speed of the amortization process is enough. ${ }^{5}$ One important thing is to see how the amortization process is done by looking at the maturity of debts and their characteristics.

In a fully amortized contract a series of payments is specified and at the end of the time the contract is fully paid. In a partially amortized contract there is a payment due at the end of the contract which is a portion of the original principal. An unamortized contract has the full original principal due at its end. (Minsky 1980a)

This is important because, in this case, an increase in the stock ratio (debt/equity or any other) may not reflect a higher fragility of the economy. As Minsky noted in 1963:

The nature of mortgage debt changed markedly between 1929 and 1962, the larger household debt-income ratio in 1962 may not indicate a greater sensitivity to a shock. (Minsky 1963a)

\footnotetext{
${ }^{5}$ Actually, no increase in the cost of external funds is necessary for $C C$ to increase.
} 
The emergence of fully amortized mortgages decreased the flow impacts of the stock of debts by increasing the maturity-matching of outflows and inflows of funds. In total, therefore, the modeling of the flow implications of any debt instrument is very important.

\section{THE CASH BOX CONDITION AND MARGINS OF SAFETY}

One central point of the Minskyan framework is the cash-flow analysis.

A key to understanding the behavior of a capitalist economy is the precise statement of the payments required by the liability structure and how the cash to meet such commitments is generated. (Minsky 1982a)

In his first extensive study about the financial instability hypothesis, published in 1964a, Minsky introduced what he called the "cash box condition". An economic unit (or the economy) has to be sure to generate enough cash inflows (CIF) or to have enough idle cash balance (IB), to meet its cash outflows $(\mathrm{COF})$ :

$$
\begin{gathered}
\mathrm{IB}+\mathrm{CIF} \geq \mathrm{COF} \\
\mathrm{IB}+\mathrm{NCF} \geq 0
\end{gathered}
$$

If the net cash inflow (NCF) is negative and no idle cash balance is available, an economic unit will be considered illiquid or even insolvent (Minsky 1984b). In addition, in order to avoid a loss of reputation and good credit (which is equivalent to a loss in net worth (Minsky 1962)), an economic unit will try to generate cash in many different ways before compromising its main activities or defaulting.

The sale, or shutdown, of strategic assets (i.e., those that generate the principal or "normal" or "basic" sources of cash inflows) is only a final solution and implies a loss of good credit (i.e., borrowing power) in addition to a loss in the cash-flow generating power of a unit. The ultimate point is, of course, a bankruptcy situation (i.e., a debt-deflation process at the aggregate level). The cash box condition, therefore, provides good insights on how an economic unit (or the economy) could get into trouble and what its margins of safety. 


\subsection{The Cash Box Condition and the Measure of Financial Fragility}

There are different sources and uses of funds for each economic activity, and depending on the main economic activity of unit, some of them will be more important than others. Also, depending on the level of analysis (individual, sector, or economy), the possible sources of funds and main net cash inflows are different. All those sources and uses can be classified in three different categories, for example, the sources of funds we have Figure 1. It shows that an economic unit can get its cash inflows from three main sources: either from its involvement in the productive process, because it lends some funds, or, finally, by issuing debts (i.e., borrowing) and assets (liquidating).

An ultimate reality in a capitalist economy is the set of interrelated balance sheets among the various units. Items in the balance sheets set up cash flows. Cash flows are the result of (1) the income-producing system, which includes wages, taxes, and nonfinancial corporate gross profits after taxes, (2) the financial structure, which is composed of as interest, dividends, rents, and repayments on loans, and (3) the dealing or trading in capital assets and financial instruments. For all except dividends, the cash flows determined by the financial structure are contractual commitments. (Minsky 1975a)

Stated alternatively, all economic activities involve income transactions, balance-sheet transactions, and portfolio transactions (Minsky 1962, 1964a, 1972b).

\section{Figure 1: Sources of Cash Inflows}

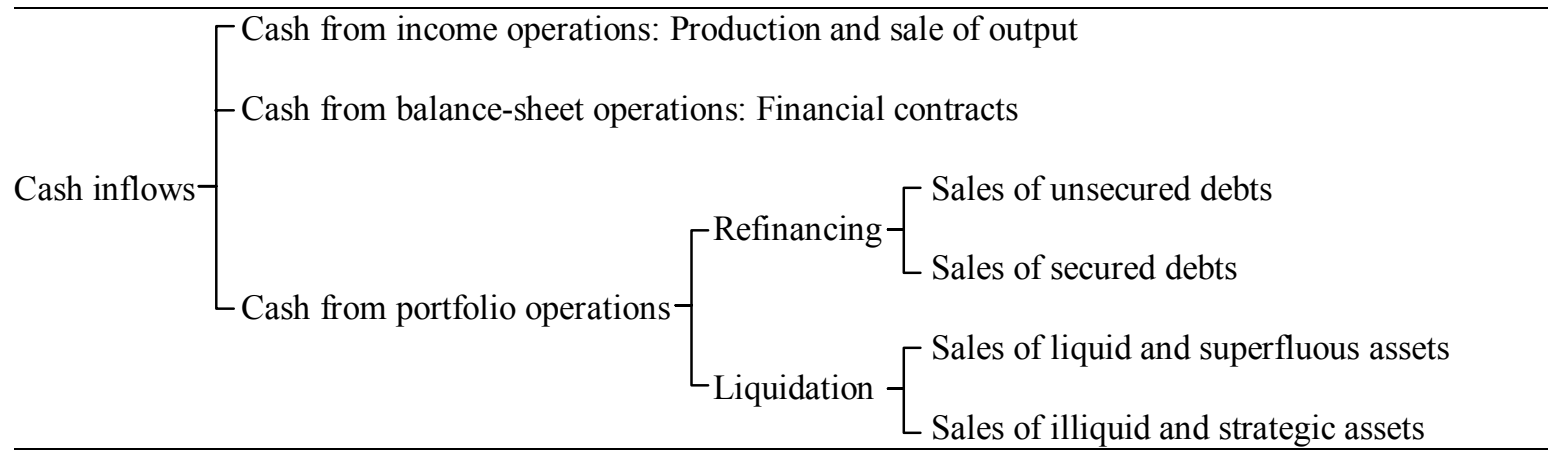

If the turnover of securities can be a normal source of cash at the microlevel, at the aggregate level liquidation is not possible, so income flows and refinancing can be considered as the only normal sources of funds (Minsky 1962, 1972b). One way to measure financial fragility 
at the aggregate level is then to look at the proportion of income transactions relative to the balance-sheet transactions and the portfolio transactions (Minsky 1962, 1964a).

Financial instability is linked to the relative importance of income, balance-sheet, and portfolio cash flows in an economy. Income cash flows [...] are the foundation upon which the balancesheet and portfolio cash flows rest. [...] An economy in which income cash flows are dominant in meeting balance-sheet commitments is relatively immune to financial crises: it is financially robust. An economy in which portfolio transactions are widely used to obtain the means for making balance-sheet payment can be crisis-prone: it is at least potentially fragile. (Minsky 1986a)

This gives an approximation of the dependence upon the need to make position, i.e., to meet balance-sheet commitments with portfolio transactions. The notion of "position making" is, indeed, central to the Minskyan approach — the more an economy is involved in positionmaking activities, the more it is dependent upon the short-term financial conditions.

\subsection{The Margins of Safety: Hedge, Speculative and Ponzi Financial Structure}

The cash box condition shows that there are several margins of safety for an economic unit. These margins of safety are essential for the working of a capitalist economy because:

The system of financing in a capitalist economy is based upon margins of safety embodied in anticipated excesses of cash receipts over payment commitments and of asset values over capitalized payment commitments. Whenever, for whatever reasons, the margins of safety in existing contracts are compromised then the ability and willingness of bankers and business to finance new expenditures and to enter into debt contracts to finance holding of capital assets are compromised. (Minsky 1984b)

Stated in terms of the cash box condition, the margins of safety represent the expected existence of a positive net cash inflow on income and balance-sheet operations $\left(E\left(\mathrm{NCF}_{\mathrm{O}}\right)>0\right)$, the expected capacity to raise cash at low cost via portfolio operations (speculation and positionmaking) $\left(E\left(\mathrm{NCF}_{\mathrm{P}}\right)>0\right)$, and the existence of a comfortable idle amount of cash and superfluous liquid assets that limits the expected need to liquidate a strategic position (IB $>0$ ). If one excludes portfolio operations as a normal source of cash, there are, therefore, three margins of safety: $E\left(\mathrm{NCF}_{\mathrm{O}}\right)>0$ ("cash-flow margin"), present value of strategic assets $\left(P_{A}\right)>$ present value 
of liabilities $\left(P_{L}\right)$ ("portfolio margin" or net-worth margin) and IB > 0 ("cash margin") (Minsky 1986a).

Those margins of safety determine the expected liquidity and expected solvency of an economic unit.

A unit is liquid if, when it has a need for cash, it can obtain cash by operating in markets that quickly, easily, and cheaply yield cash. Ultimately, the liquidity of an institution depends upon the way it would obtain cash if some need to do so should arise. (Minsky 1975c)

If $E\left(\mathrm{NCF}_{\mathrm{O}}\right)>0$, a unit is considered liquid in normal time. If $P_{A}>P_{L}$, a unit is considered solvent (i.e., it is expected to be liquid for the whole period of its existence); finally, the structure of assets and liabilities (quality, maturity, liquidity, proportion) plays on both the solvency and the liquidity of a unit.

Minsky classified these considerations in the famous three financial structures: hedge, speculative, and Ponzi (Minsky 1974). Table 1, based partly on Minsky (1972b, 1980a, 1986a), provides a characterization of those financial structures. The whole point of these different situations is to look at the relationship, both in terms of flows and in terms of stock, between the cash inflows from income production and distribution and the cash outflows from balance-sheet commitments. The cash outflows from balance-sheet operations are multiple and do not correspond only to debt services. They contain all cash-flow commitments determined by the dated (due at a specific date or time schedule), demand (honored at the will of the creditor), and contingent (honored at the will of the creditor if specific events are realized or due at specific date) contracts/liabilities (Minsky 1962, 1964a, 1964b, 1972a); dividends, leases, rents, insurance premiums, margin calls are among them. The narrowest way to present the different financial situations is to include only debt services and to show that if interest payments cannot be covered, a unit will have to borrow more (Minsky 1978). In addition, the term "liabilities" is here taken in a broad sense; dated off-balance-sheet, demand or contingent liabilities also matter. Examples of, dated off-balance-sheet items are insurance and rental contracts (Minsky 1964a). Demand off-balance sheet items are contractual (rather than informal) credit lines (Minsky 1969b) and contingent off-balance-sheet items are derivative contracts. All of these financial commitments lead to payments that have to be met, usually whatever the cash inflows of a unit. 
Table 1: Stock and Flow Characteristics of Financial Positions

\begin{tabular}{|c|c|c|c|}
\hline & Hedge & Speculative & Ponzi \\
\hline $\begin{array}{l}\text { Cash-flow } \\
\text { Margin } \\
\text { (Liquidity) }\end{array}$ & $\begin{array}{l}\text { Therefore: } \\
E\left(\mathrm{NCF}_{\mathrm{PM}}\right)=0\end{array}$ & $\begin{array}{l}E\left(\mathrm{NCF}_{\mathrm{O} t}\right)<0 \forall t \text { small } \\
\text { with } \\
E\left(\mathrm{CIF}_{\mathrm{O} t}\right)=E\left(\mathrm{COF}_{\mathrm{O} t}-a L_{t}\right) \\
\text { Therefore: } \\
E\left(\mathrm{NCF}_{\mathrm{PM}}\right)=E\left(a L_{t}\right)>0\end{array}$ & $\begin{array}{l}E\left(\mathrm{NCF}_{\mathrm{O} t}\right)<0 \forall t<n \\
\text { with } \\
E\left(\mathrm{CIF}_{\mathrm{O} t}\right)=E\left(\mathrm{COF}_{\mathrm{O} t}-(i+a) L_{t}\right) \\
\text { Therefore: } \\
E\left(\mathrm{NCF}_{\mathrm{PM}}\right)=E\left((i+a) L_{t}\right)>0\end{array}$ \\
\hline $\begin{array}{l}\text { Net worth: } \\
\text { Portfolio } \\
\text { margin } \\
\text { (Solvency) }\end{array}$ & $P_{A}>P_{L} \forall i, g, E\left(\Delta P_{A}\right)$ & $P_{A}>P_{L}$ for some $i, g, E\left(\Delta P_{A}\right)$ & $P_{A}>P_{L}$ for some $i, g, E\left(\Delta P_{A}\right)$ \\
\hline $\begin{array}{l}\text { Balance- } \\
\text { sheet: } \\
\text { Cash } \\
\text { margin } \\
\text { (Liquidity/ } \\
\text { Solvency) }\end{array}$ & $\begin{array}{l}\text { Assets: Some cash and cash } \\
\text { kickers. } \\
\text { Liabilities: } \\
\text { Debts are mainly long-term } \\
\text { debts. } \\
\text { Long-term debts with sinking } \\
\text { funds arrangements. } \\
\text { Low proportion of contingent } \\
\text { and demand liabilities. } \\
\text { No or insignificant proportion } \\
\text { of debts with floating rates. } \\
\text { Maturity: No or few } \\
\text { mismatches between assets } \\
\text { and liabilities. }\end{array}$ & $\begin{array}{l}\text { Assets: Cash kickers in high } \\
\text { proportion, cash. } \\
\text { Liabilities: } \\
\text { Long-term debts. } \\
\text { Demand and contingent short- } \\
\text { term debts. } \\
\text { High proportion of floating } \\
\text { rate debts. } \\
\text { Maturity: } \\
\text { mismatches between assets } \\
\text { and liabilities. } \\
\text { Off-balance-sheet: } \\
\text { Credit lines. } \\
\text { Rapid access to markets is } \\
\text { available. }\end{array}$ & $\begin{array}{l}\text { Assets: Cash kickers in low } \\
\text { proportion, few cash. } \\
\text { Liabilities: } \\
\text { Short-term debts in high } \\
\text { proportion. } \\
\text { No reliable source of funds. } \\
\text { Maturity: Large mismatches } \\
\text { between assets and liabilities. }\end{array}$ \\
\hline
\end{tabular}

In a hedge situation, there is no expectation, even with relatively conservative expectations of cash inflows (Minsky 1980a), that the cash inflows from income production and distribution will be less than the cash outflows on balance-sheet commitments:

$$
E\left(\mathrm{NCF}_{\mathrm{O} t}\right)>0 \forall t
$$

This is so for most of the considered possible variations in cash inflows, interest rates, maturities, and other cash-outflow related characteristics of liability contracts. Therefore, there is no expectation that one will have to make position. However, some idle cash and superfluous liquid

\footnotetext{
${ }^{6}$ Note that this only characteristic can make an economic unit go from hedge to speculative situation. Hedge financing with floating rates is considered speculative because of the dependence on changes in financial market conditions (Minsky 1986a).
} 
assets are kept aside to meet possible disappointments in expectations (Minsky 1975b). ${ }^{7}$ In addition, the external refinancing sources of a hedge unit are very reliable and based on longterm commitments with bankers. In the end, therefore, a hedge unit is expected to be very liquid. All this leads to a strong balance-sheet position in which the market value of assets is superior to the market value of debts, even for very large changes in interest rates, expectations of income growth $(\mathrm{g})$ and capital gains $\left(E\left(P_{A}\right)\right)$.

For a speculative economic unit, it is expected that cash inflows from the main economic activity will not cover the capital component of cash commitments (e.g., amortization of debts and margin calls) induced by balance-sheet commitments, even if all income commitments from balance commitments (rent payments, dividend payments, insurance premium, and others) can be paid. In its cash-flow aspect, a speculative situation is one in which $E\left(\mathrm{NCF}_{\mathrm{O}}\right)<0$, at least in the short term. For an economic unit, this means that the cash inflow from its main income or balance-sheet operations is not enough to cover the cash outflow from the balance-sheet operations: ${ }^{8}$

$$
E\left(\mathrm{NCF}_{\mathrm{O} t}\right)=-E\left(a L_{t}\right) \forall t \text { small }
$$

Therefore, an expected refinancing (or liquidation) is necessary, but only for the capital component of debt service $(a L)$, so there is no expected increase in liabilities. ${ }^{9}$ This need for refinancing is, however, a flaw in the financial structure of the unit because:

Where a hedge-financing unit is dependent only upon the normal functioning of product and factor markets (or for a financial unit, upon fulfillment of contract), a speculative unit is dependent upon the normal functioning of product, factor, and money markets. (Minsky 1986a)

A speculative unit may get into trouble more easily and by more channels than a hedge unit and will be more sensitive to changes in interest rates for its flow and stock variables. Indeed, an

\footnotetext{
${ }^{7}$ In addition, if some cash commitments are denominated in other units of account than the main cash inflows, some cash and liquid assets denominated in the former are kept idle (Minsky 1980a).

${ }^{8}$ For dealers and all agents who obtain their basic cash inflow from portfolio operations, a speculative position is one with $\mathrm{E}\left(\mathrm{NCF}_{\mathrm{S}}+\mathrm{NCF}_{\mathrm{O}}\right)<0 . \mathrm{NCF}_{\mathrm{S}}$ represents the net cash flow from the speculative turnover of financial assets (capital gains net of the cost of turnover), and $\mathrm{NCF}_{\mathrm{S}}+\mathrm{NCF}_{\mathrm{PM}}$ are all the net cash flows from portfolio operations so that $\mathrm{NCF}=\mathrm{NCF}_{\mathrm{O}}+\mathrm{NCF}_{\mathrm{P}}$ (Minsky 1969b). Following Minsky, we leave aside $\mathrm{NCF}_{\mathrm{S}}$ unless appropriate (one case for which it would be appropriate is when capital gains are not enough to pay the pension of retirees).

${ }^{9}$ If possible at low cost, refinancing is preferable to liquidation because there is no decrease in net worth and so no decrease in the borrowing power. A stricter definition of speculative finance excludes all the capital components of the cash inflows from balance-sheet operations (e.g., cash received from principal payments or margin gains if they are paid by cash).
} 
increase in interest rates will increase the cash outflows and so increase the gap between expected inflows and expected outflows from operations and contracts. In addition, the market value of assets will decrease more rapidly than that of liabilities because they are affected by a higher discount rate. Finally, for a speculative unit, the cash margin is lower in size and less liquid in its structure. Typically it will depend more on liquid assets and on quick access to shortterm sources of cash. This lower protection from possible disappointments of expectations leads to a higher sensitivity of asset prices and to changes in income growth and capital-gain expectations.

A Ponzi finance is the same as a speculative finance situation, except that the cash-flow, portfolio, and cash margins are thinner, and the ways to get cash to make position are more "volatile and exotic sources" (Minsky 1980a, 1975d). Indeed, the Ponzi situation is a special case of the speculative situation in which refinancing operations lead to a decrease in net worth.

With speculative finance, net worth and liquidity can increase even as debt is refinanced, whereas for a Ponzi unit net worth and liquidity necessarily decrease. (Minsky 1986a)

The refinancing need concerns not only the capital components of balance-sheet cash commitments but also their income components (Minsky 1986a). A Ponzi finance situation does not necessarily lead to an increase in debt if the liquidation of assets or the running down of idle cash are preferred alternatives (Minsky 1977a). Speculative finance may lead to a decrease in net worth if liquidation is preferred to refinancing.

In addition, in the case of Ponzi finance, the net worth is negative for "any honest computation of present value" (Minsky 1977c). However, there is still a hope that the net worth will turn positive in an undetermined future, otherwise the unit could never issue new debts. If, for example, Ponzi finance is used for the production of investment goods, then there is a potential future increase in the cash-flow generating power, and so net worth may rebound in the future. However, only when a finished new capital good is involved in the productive process does it have any value, and so it can increase the net worth of its owner (Minsky 1986a). Thus, a Ponzi situation can be called "capitalization of interest" finance and a speculative finance is equivalent to "rollover" finance (Minsky 1982b): 


$$
E\left(\mathrm{NCF}_{\mathrm{O} t}\right)=-E\left((i+a) L_{t}\right) \forall t<n
$$

where $i L$ represents all the income components of the cash outflows on balance-sheet commitments.

One important characteristic of both speculative situations is that they maintain or increase the liability side of balance sheets without increasing the cash-flow generating power of the unit (or of the economy) - they generate unproductive loans. Applied to the aggregate level, a Ponzi situation means that:

The payment commitments on debts are increasing as interest is capitalized, even as the ability to acquire profits is not enhanced by investment. (Minsky 1991c)

In addition, Ponzi and speculative finance are done with short-term sources of funds so their practice increases the sensitivity of a unit, a sector or an economy to change in the cost of refinancing or the cost of liquidation. Minsky argued that "there are both rational and market processes which lead firms households, and financial institutions into speculative finance" (Minsky 1975b).

In period of euphoria, Ponzi finance can be sustained because of the convention in place or because of the amount of money at stake.

Ponzi units can be sustained either because of Micawber sentiments - something will turn up - or because no one is willing to announce that "the Emperor has no clothes." (Minsky 1975c)

It is not in the interest of the persons involved in a Ponzi process to recognize that the whole operation is based on highly doubtful objectives.

Ponzi finance, therefore, does not mean that an economic unit is involved in fraudulent economic activities. Ponzi finance can take many forms more or less interesting for the study of financial instability. An example of "uninteresting" Ponzi situation is when the seasonal gross profit may not be enough to pay fixed quarterly dividend payments (Minsky 1986a). Examples of interesting Ponzi situations are (Minsky 1980a, 1984b): borrowing funds to buy securities where income will never cover debt-service payments (only capital gains can make the operation profitable), the acquisition of expensive capital assets with a long maturity, and any other 
situations where the income generated by the holding of an asset is durably expected to be lower than the total (i.e., income and capital part) of the carrying cost of the asset. Finally, it is important to note that Ponzi financing can be hard to detect because it can be hidden by creative accounting practices (Minsky 1989c).

\subsection{Conclusion}

One central conclusion from the preceding is that the cash box condition of each economic sector has to be understood thoroughly. The relationship between nominal cash inflows and nominal cash outflows is extremely important. Purchasing power concerns, in addition to being misleading, are secondary concerns and are included in the financial power concerns presented above.

In order to be more concrete, the following example is provided. Say that workers earn a wage of $w=\$ 5$ and have to pay $C C=\$ 2$ each month to service their debt, and assume that the general price level is $P=\$ 1$. The real wage earned by workers is $w / P=\$ 5$ and the net wage of workers is the nominal wage less the cash commitments in the form of debt-service payments, $w-C C=\$ 3$. Say now that workers obtain a raise that doubles their wage so that $w=\$ 10$, and that the general price level is also doubled $P=\$ 2$. The real wage of workers is thus the same but the situation of workers has considerably improved. Indeed, the financial power of money and the capacity of workers to face their debt commitments (the liquidity of their position) is largely improved, $w-C C=\$ 8$. This improvement in their financial power increases their financial wealth (assuming that their real consumption level is unchanged) ${ }^{10}$ and gives them easier access to bank loans and financial independence. As Keynes says, the recommendations of Classical economists forget about this:

Nor are they based on indirect effects due to a lower wages-bill in terms of money having certain reactions on the banking system and the state of credit. (Keynes 1936)

\footnotetext{
${ }^{10}$ Say that $C=P Q_{c}=\$ 1 \times 3=\$ 3$ : workers consume all their net income. In the second period, if $Q_{c}$ is the same $C=$ $\$ 6$ and so workers can save $\$ 2$. This increase in their financial wealth improves the collateral they can offer to bankers when they ask for loans, and so the willingness to lend of bankers is higher. Another way the financial wealth can increase is, if $P$ does not change but $w$ rises to $\$ 10$ then the real burden of debts $(C C / P)$ is unchanged but still workers are better off because of the lower nominal burden of their debts.
} 
Actually, the improvement in the financial wealth is not necessary to conclude that workers are better off. Say that $C C$ also increases by $\$ 2$ so that $C C / P$ and $w / P$ are unchanged, still the situation of workers has improved because their position is more liquid $(w-C C=\$ 6)$. Note also that the real burden of debts $(C C / P)$ is a misleading concept for workers because even if prices change, their debt burden is unchanged; only wage changes will affect the burden of debt. Thus, the real burden of debt or the real wages are not what matter for economic agents.

Therefore, in a monetary production economy, nominal variables matter more than real variables. Economic agents pay a lot more attention to protecting themselves against insolvency rather than to the narrow problem of the purchasing power of their monetary hoards or income gains.

Liquidity is a fundamental recurring problem whenever people organize most of their income receipt and payment activities on a forward money contractual basis. For real world enterprises and households, the balancing of their checkbook inflows against outflows to maintain liquidity is the most serious economic problem they face everyday of their live. (Davidson 2002)

The role of real variables should be left for historical comparison, not for current economic analysis (Keynes 1933, 1936).

\section{ACCUMULATION PROCESS : TWO PRICE SYSTEMS WITH TWO SETS OF PRICE, FINANCIAL STRUCTURE, AND THE KALECKI EQUATION OF PROFIT}

\subsection{The Determination of Aggregate Profit}

From 1977 on, Minsky (1977b, 1978, 1986a, 1991b) preferred to use Kalecki's equation of aggregate profit (Kalecki 1971) rather than Kahn's multiplier analysis (Kahn 1931) to explain the determination of aggregate income. The level of aggregate gross profit after tax, $\Pi \equiv \Pi^{*}-$ $t_{\Pi} \Pi^{*}$ (with $t_{\Pi}$ the tax rate on gross profit), is determined by (Kalecki 1971; Sawyer 1985; Minsky 1986a):

$$
\Pi=I+(G-T)+(X-J)+C_{\Pi}-S_{W}
$$


This equation is derived from the expenditure and income approaches to the GDP identity. However, the identity is transformed into equality by the behavioral and causal assumptions that are assumed to exist in the economy. As Kalecki argues, $\Pi$ is not under the control of any economic agents whereas, $I$ (investment expenditures), $G$ (public expenditures), $X$ (exports), $J$ (imports), $C_{\Pi}$ (consumption out of distributed profits), and $S_{W}$ (workers' saving out of wages) are determined by a decision process (Kalecki 1971).

One central point of this equation is to show that there are two leading variables in the economic system: $I$ and $G$ (Minsky 1986a). These two variables are not determined by the current level of aggregate income (even if they may be influenced by it), and aggregate public expenditures can be used to stabilize the adverse effect of a decrease in aggregate investment on aggregate profit. Another important point is that aggregate profit is determined independently of the mark-up that firms put in their price. It is the structure of aggregate demand that determines the mark-up, and more precisely, it is in the consumer-good sector that the aggregate mark up is generated via the spending of economic actors who do not work in the consumer good sector (Minsky 1986, 1982a; Kalecki 1971).

The framework yields a macroeconomic theory of profits in which profits exist not because capital is productive but because investment demand makes consumption output scarce. [...] Profits arising in the production of consumer goods are due to spending on consumer goods in excess of the wage bill generated by the production of consumer goods. (Minsky 1986b)

The microeconomic decisions over the mark-up only influence the distribution of the aggregate profit (Minsky 1986a).

From the aggregate determination of profit, one can then derive the determination of internal funds by using:

$$
\Pi_{I F}=\Pi-(i+a) L
$$

Of course, depending on the debt structure, there may be different types of interest rates and amortization rates, and, in this case, it is necessary differentiate between them. More generally, $i L$ represents all the income components of the cash outflows on balance-sheet commitments, and $a L$ represents all the capital components of cash outflows on balance-sheet commitments. 
For the business sector, the level of liabilities (both in- and off-balance sheet liabilities), their interest (or income) level, and their maturity determine the minimum gross profit that needs to be generated in order to be able to meet cash commitments without having to make position.

\subsection{The Determination of the Investment Level}

Graphically, the determination of the level of investment is based on a Marshallian supply and demand analysis augmented with the Kalecki's principle of increased risk (Minsky 1967b, 1975a, 1986a, 1989d; Kalecki 1971). This mainstream representation, however, does not fit the theoretical framework used by Minsky. At the aggregate level, Kalecki's equation of profit is added to the system and the Neoclassical approach to output prices is replaced with Weintraub's method of output price determination. The principle of increasing risk is still there and states that, as expected external funding increases, there is an expected increase in the debt-equity ratio, which affects the perceived risk of engaging in an economic activity with external funds. This perceived risk may be completely unfounded and, as Lavoie (1997) notes, there are forces that may lead to a decrease in actual risk. However, the preceding does not put into question the relevance of this concept for the micro or macro level as long as one stays in the realm of expectations.

The profit equation and the principle of increasing risk reflect the importance of financial factors for the determination of investment. The modeling of the latter dependence changed over time, starting with a loanable funds theory framework (Minsky 1957b, 1959, 1964a, 1965a) and ending with a framework based on chapter 17 of Keynes's General Theory (Minsky 1975a, 1986a). In any case, the importance of both relative prices and financial structure (both desired and actual) is put forward by Minsky as central for the determination of the investment level.

\subsubsection{The Micro Determination of Investment}

At the level of one enterprise, the level of investment is determined in the way shown by Figure 2. An entrepreneur compares the demand price $\left(P_{I d}\right)$, that is the price $\mathrm{s} /$ he is ready to pay for a certain type of investment good, with the price at which the producer of the investment good offers the latter $\left(P_{I s}\right)$. 
Figure 2: Microeconomic Determination of Investment Demand for a Certain Type of Investment Goods

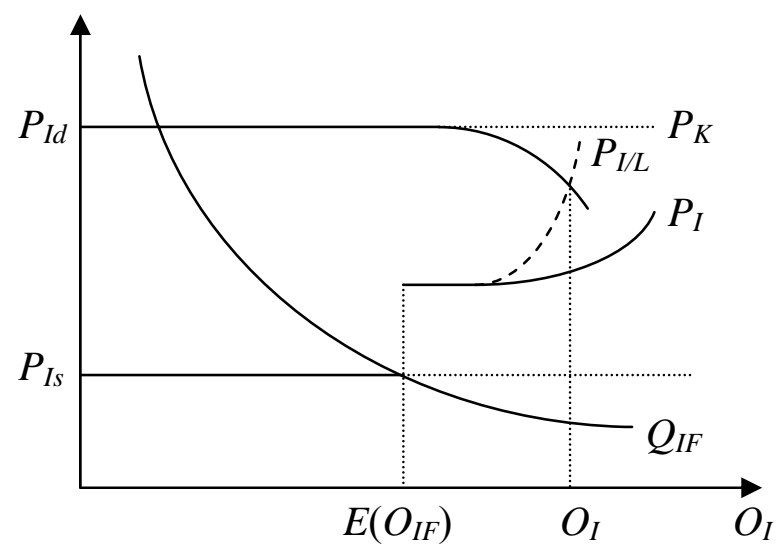

The demand price represents the discounted expectations of the entrepreneurs and reflects the long-term side of the investment process:

$$
P_{I d}=D_{K}[Q]
$$

with $Q$ the expected gross quasi-rent over the life of the investment goods (long-term expectations) and $D_{K}$ the discount factor (which depends on long-term interest rates). The latter reflects the entrepreneur's risk (or borrower's risk if investment is externally funded), which represents the confidence of the entrepreneur in the future. Because of his/her vision of the future, an entrepreneur has a given desired level of investment, as well as a desired funding structure of this investment. Therefore, as the level of investment increases, the entrepreneur's risk increases and this leads to a decrease in the demand price. The decrease does not need to start when investment begins to be externally funded; it can happen before or, usually, after (Minsky 1975a) because the entrepreneur's risk does not depend only on the level of external funding. Indeed, another major variable that affects the discount factor put of demand price is the (marginal) user cost of money, i.e., the implicit rate of return on money (Keynes 1936, Kregel 1997). This is so because an entrepreneur has to choose between different types of assets, and the choice will depend on the relative profitability and liquidity of each of them. As Minsky said, capital assets can be "best thought as a special type of financial instrument" (Minsky 1977c) in the sense that they are expected to generate an income but their liquidity is nil or very low (Minsky 1975a). 
The "offer price" (Minsky 1982a), $P_{I s}$, represents the short-term side of the investment decision. It is a horizontal line because it is assumed that the buyer does not have any influence on the cost of production of the producer. The offer price is determined by a mark-up over the marginal cost of production. The mark-up depends, in part, on the user cost of capital equipment, that is, the expectation of profits in the near term relative to current expected profit (short-term profit expectations) (Minsky 1971). More precisely, the marginal user cost of capital equipment determines the minimum mark up necessary to give to the producer the incentive to produce (Keynes 1936):

$$
P_{I s}=\lambda c
$$

However, a producer may be forced to produce even if the price is below its minimum required level, because a producer may have to meet contractual financial commitments (Minsky 1975a, 1971). The mark-up depends also on the short-term cost of financing production (short-term interest rate and amortization rate) that is generated by borrowing to pay wages, raw materials and other costs of production, and on the market power of the firm (Minsky 1978, 1986a).

However, if part of the quantity of investment goods acquired $\left(O_{I}\right)$ has to be externally funded, the offer price is not, from the buyer's point of view, the relevant cost of new capital goods. Indeed, it is also necessary to include the cost of the external funds. The supply price of capital, its "delivered price" (Minsky 1978), is equal to the sum of the offer price plus the discounted value of the cash-flow commitments: $P_{I}=P_{I s}+D[C C]$ (Minsky 1975a). This leads to a jump in the supply price function when investment has to be externally funded (above $E\left(O_{I F}\right)$ ). The supply price, then, becomes an increasing function of the level of investment because of the lender's risk. The latter reflects the vision of the future of bankers. This vision of the future sets some acceptable margins of safety to meet, which reflect what bankers see as an appropriate or "optimal" financial structure. As investment expenditure increases, the expected increase in debt relative to equity leads to an increase in the perceived risk of the investment operation. The strength of this risk (the curvature of the supply price) depends on how loose the bankers' convention is.

Finally, if an entrepreneur was previously indebted, there is an additional cost to add induced by the refinancing of existing positions, what Minsky call the "marginal lender's risk" 
(Minsky 1975a). This leads to the supply price curve $P_{I / L}$. In the next figure, no difference is made between lender's risk and marginal lender's risk.

The level of investment is, therefore, determined by the demand and supply price of investment and by what entrepreneurs and lenders think is an appropriate method of funding investment. The latter depends on the conventional margins of safety of entrepreneurs and bankers. This, in turn, depends on their vision of the future, i.e., their state of long-term expectation. If considerations about the financial structure were not included, the level of investment would be limited only by the entrepreneur's risk. ${ }^{11}$

The desired structure of investment funding is determined by the expected amount of net quasi-rent $\left(Q_{I F}\right)$ and the desired/expected external funding of investment $\left(E\left(\Delta L_{I}\right)\right)$. In the following, the former is equal to expected internal funds with sales as the only source of cash inflows in the $\mathrm{NCF}_{\mathrm{O}}$ of the entrepreneur. The expected "internal financing constraint" (Minsky $1975 \mathrm{a})$ is, $Q_{I F}=P_{I s} \cdot E\left(O_{I F}\right)$, which gives the quantity of investment goods that can be bought with internal funds: $E\left(O_{I F}\right)=Q_{I F} / P_{I s}$. The difference $O_{I}-E\left(O_{I F}\right)$ represents the expected quantity of investment goods that will be bought by requesting external funds. This is expected to lead to an increase in the cash-flow commitments $(E(\Delta C C)>0)$.

\subsubsection{The Macro Determination of Investment}

In the microeconomic approach, "all prices and prospective yields are independent of the firm's own scale of operations" (Minsky 1975a). At the macroeconomic level, this does not stand anymore for several reasons. First, at the macroeconomic level, it is necessary to differentiate between two price systems with two sets of prices (Kregel 1992; Minsky 1969a, 1969c, 1975a, 1977b, 1978, 1986a, 1996). The first price system is the flow-price system (or output-price system) $P_{O}$, which is the "carrier of profit" (Minsky 1986a). Indeed, it contains two sets of prices, one concerning consumption goods $\left(P_{C}\right)$ and another one concerning investment goods $\left(P_{I s}\right)$, and both are important to determine the profit level in each sector. The second price system

${ }^{11}$ Minsky stated that investment would be unlimited (Minsky 1975a) but he failed to take into account the entrepreneur's risk independently of the borrower's risk. More precisely, he stated that if there were no risk, no uncertainty and no consideration about financial operations, the demand for investment would be unlimited for an entrepreneur (Minsky 1975a). Demand price and supply price would be horizontal. At the aggregate level, assuming decreasing returns, the only limit would be the cost of producing investment so that $O_{I}$ would be determined when $P_{I s}$ reaches a horizontal $P_{I d}$. 
is the stock-price system (or asset-price system) $P_{A}$ (Minsky 1977b). The latter contains the crucial distinction between price of liabilities (monetary assets), and price of capital assets (nonmonetary assets), $P_{K}$ (Keynes 1936).

There are two levels to the 'two prices' approach: The first level, presented in the Treatise, distinguishes between the prices of current output and capital goods output; the second level, added in the General Theory, distinguishes the prices of new and existing capital assets from the prices of new and existing financial liabilities. (Kregel 1992)

Each component of this price system is influenced by the developments taking place inside the economic system. The output price system depends on the level of aggregate demand because the latter affects both the average productivity of labor and the aggregate mark-up. The aggregate price level is:

$$
P_{O}=w / A P_{L}+\Lambda_{O}
$$

with $A P_{L}$ the average productivity of labor and $\Lambda_{O}$ the aggregate mark up that is determined by the Kalecki equation of profit. Applied at the investment sector level, one has: ${ }^{12}$

$$
P_{I S}=w / A P_{L I}\left(O_{I}\right)+\Lambda_{I}
$$

with $A P_{L I}{ }^{\prime}\left(O_{I}\right)<0$ and $\Lambda_{I}$ determined by the funding needs of the entrepreneurs of the investment sector, and by the profit expectations of entrepreneurs and other "supply conditions of the investment output" (Minsky 1982a; Lavoie 1992).

The aggregate price level for asset prices is also a function of what is happening inside the economic system. The value of those assets is socially determined by an anchor - the normal price. Economic prosperity leads to an increase in this price, which affects back investment via the effect of the price of liabilities and capital assets on the demand price for investment. This latter price has no concrete existence, rather it is an implicit variable that is approximate by the price of old capital assets, $P_{K}$, because it is assumed that firms would never buy new assets if there is the equivalent for cheaper available in secondary markets (Keynes

\footnotetext{
${ }^{12}$ Weintraub (1978) and Minsky (1986a) have studied in detail the origins of the mark up in the consumer-price sector.
} 
1936). $P_{K}$ is determined not only by the entrepreneurs' expectations, but also by the expectations prevailing in the financial markets. In fact, $P_{K}$ is still an implicit price, and if one wants to give a concrete counterpart to this variable, the best approximation that we have is the price of financial assets, which are not determined by entrepreneurs (Minsky 1986a).

In a capitalist economy, an implicit price system of capital assets - the real capital of the economy - is determined in markets, just as is the price system of current output. This implicit price system is buried in the explicit price system of shares and bonds visible in financial markets and in the prices set in mergers and acquisitions. [...] The starting point for bids on existing firms is the market valuation of the equity and debt liabilities. (Minsky 1986d)

This approximation is then discounted by the entrepreneur's risk to give an approximation of the demand price of new capital goods. Thus, we have:

$$
P_{A} \rightarrow P_{K} \rightarrow P_{I d}=P_{K}+\text { entrepreneur's risk }
$$

Therefore, to give an explicit counterpart to $P_{I d}$, one has to assume several approximations that partly divorce $P_{I d}$ from the direct decision process of entrepreneurs (the entrepreneur's risk is still a factor only determined by entrepreneurs, even if the latter may be influenced by the opinion prevailing in the financial markets (Keynes 1936)). Minsky was careful to say that this series of approximations is not very satisfactory because the link between stock markets and investment is not well known (Minsky 1969a). However, sometimes he oversimplified the matter by blankly stating that both $P_{I d}$ and stock market prices are the same (Minsky 1996).

Another important variable that affects investment, even if only indirectly and progressively, is the level of aggregate profit. The latter is a function of the actual level of investment. It is very important to differentiate between $Q$ and $\Pi$ by looking at how they are determined and how they affect each other. First, $Q$ is determined at the microeconomic level by the state of long-term expectation of entrepreneurs and bankers, whereas $\Pi$ is macroeconomically determined. Second, $I$ is determined partly by $Q$ and $\Pi$ is determined by $I$. Therefore, the more entrepreneurs invest, the more they will be able to realize their expectations and inversely. There is the following feedback process going on at the aggregate level: 
Expectation about future $\rightarrow Q+$ normal margins of safety $\rightarrow P_{I d} / P_{I} \rightarrow I \rightarrow \Pi$

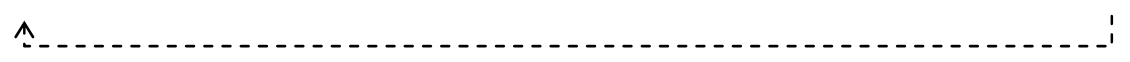

("progressively" (Minsky 1980a )

This "circularity of a capitalist economy" (Minsky 1986a) is part of the internal flaw of the capitalist economic system. However, entrepreneurs usually have no knowledge of this process or do not take it into account in their decision process. This possible frustration of expectations by macroeconomic forces is essential for the dynamics of the Minskyan system.

Figure 3 shows how investment is determined at the aggregate level. Again, it is very important to understand that the structure of funding is an expected structure, where $Q_{I F}$ is used to determine $E\left(O_{I F}\right)$. The actual funding structure, determined by $\Pi$, has important feedback effects on the behavior of individuals and their willingness to go into debt and to lend in order to invest. The main difference with the micro-determination (aside from $P_{I s}$ that now depends on $\left.O_{I}\right)$ is that the actual internal financial constrain becomes endogenously determined: $\Pi_{I F}(I)=$ $P_{I S} \cdot O_{I F}$ (Minsky 1975a). Minsky does not make a clear difference between $Q$ and $\Pi$ and assumes directly $Q(I)$. This is not acceptable as one stays in the Keynesian methodology of shifting equilibrium (Kregel 1976). One must assume that the state of expectations is only progressively affected by investment (via the level of profit), which is actually what Minsky assumes.

\section{Figure 3: Macroeconomic Determination of the Level of Investment}

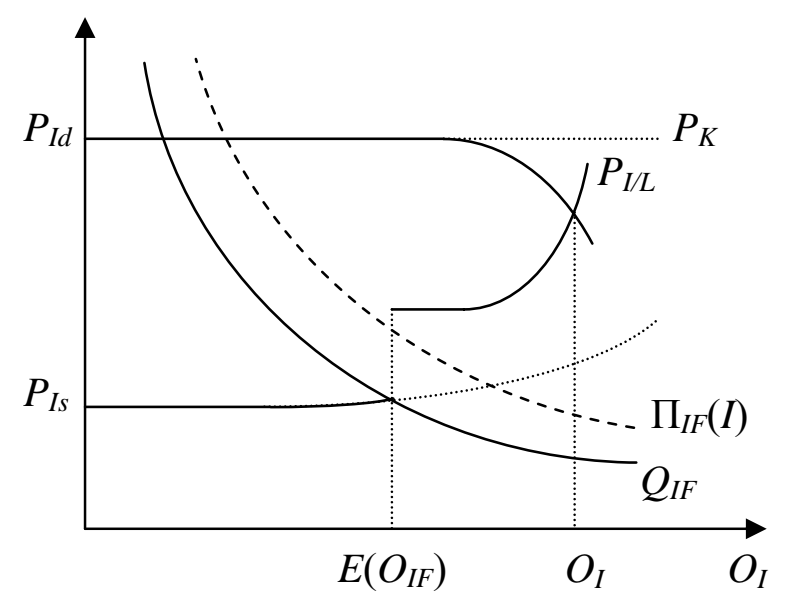




\section{THE FINANCING AND FUNDING PROCESS}

The different economic activities can all be classified in relation to two different categories (Minsky 1983a, 1984a, 1990b): the production of assets and the carrying of assets. Therefore, money is used for both "financing activity and taking positions in inherited assets" (Minsky 1977b); the second case includes the acquisition and maintenance of positions in existing financial and real assets. All these economic activities are supported by a financing and funding process that involves a flux of money (via monetary creation) and a reflux of money (via spending and borrowing of existing liquid savings). The funding process includes also the rollover (i.e., the renewing of the same loans), renegotiation (change in the terms of contracts), or consolidation (borrowing long-term to reimburse short-term debts) of existing financial contracts, all of which can be classified as "refinancing" activities, and which emerge, in the simplest model, from the fact that some households desired to keep part of their saving in monetary form (Davidson 1978; Lavoie 1987, 1992; Parguez 1984). All types of economic agents (except the authority that issues the top IOUs) may have refinancing needs ${ }^{13}$ and all agents have financing needs.

As the pyramid of IOUs showed, all units need to be financed in the sense that all units need to have their IOUs accepted in order to be able to implement their economic decisions. The acceptance is based on the promise of the issuer of IOUs (except the federal government) ${ }^{14}$ to be able get a third party IOU, usually higher or of the same level, in the hierarchy. Depending on the type of liability, this promise can be demand, dated, or contingent, and, if this promise cannot be satisfied by normal operations, then a refinancing operation or a liquidation is necessary.

Refinancing is a normal operation for banks. Indeed, because they do not wait for the resources to lend, and because they promise to convert their IOUs in central bank IOUs on demand, banks need to borrow or to buy some reserves to be able to fulfill their obligations. In

\footnotetext{
${ }^{13}$ More precisely, refinancing operations for the top issuer are used, not to obtain funds, but to change the maturity structure of its outstanding debt (either to push back interest payments in the future or to satisfy the needs of the private sector for long-term, low risk assets).

${ }^{14}$ This is, of course, not true if the government issued IOUs in foreign currencies or if it promises a conversion on demand of its on IOUs in other assets or IOUs that it cannot create (gold, foreign currency, etc.). However, usually, because their IOUs are at the top of the pyramids of IOUs, governments can "more than other units issue debts to pay debts" (Minsky 1984b): coins, notes, bonds, etc. are all IOUs of the government and the mere shift between them does not change government indebtedness (reimbursing T-bonds with coins, notes, or reserve credits, does not decrease the government debt, it only changes its structure).
} 
fact, all agents that have a maturity of their assets that is longer than that of their debts need to be refinanced.

These financial needs contribute to the inelasticity of loan demand to interest rates. The demand for loans can even be positively correlated to interest rates depending of the size of indebtedness of the sector or the economy.

Thus when an investment boom takes place in the context of an enlarged need to refinance maturing debt, the demand 'curve' for short-term debt increases (shifts to the right) and becomes steeper (less elastic). (Minsky 1982b)

Indeed, when some commitments are due and a unit cannot meet them with the cash flow from its normal operations, this unit will pay whatever is necessary to fulfill its commitments in order to avoid a loss of reputation and bankruptcy, with the ultimate solution being the liquidation of strategic assets. This refinancing situation is more often triggered for economic projects that take a long time to mature, like investment projects. More generally, all speculative financial structures, that is, all structures that rest on the holding of assets for which income does not cover their carrying cost for a determined or an undetermined period, need access to a reliable refinancing source.

All the preceding has several implications for the modeling process. Again, the most important one is that a model cannot represent Minsky's theory if there is no reference to the process of financing and funding.

It is impossible to draw a meaningful investment demand function without simultaneously specifying the liabilities that will be emitted. (Minsky 1967b)

"Money is never neutral" (Minsky 1993, italics added) because of its necessity to satisfy the financing and funding process of the economy and to calm the nerves of economic agents in face of uncertainty. One cannot assume that money is dropped from helicopters or "rains down from Heaven" (Friedman 1969). A second implication is that there is no reason to assume an automatic relationship between the demand for bank loans and interest rates. Depending on the level of indebtedness, this relationship can change.

Another important conclusion from the preceding is that Minsky's theory does not rest on the loanable funds theory. By 1969, the theory no longer contains any explicit or implicit 
references to the loanable funds theory and the possibility of financing or funding via exante saving. In addition, Minsky dropped the textbook liquidity preference theory for Keynes's liquidity preference theory as exposed in chapter 17 . From this time, Minsky never made any more reference to the loanable funds theory of the rate of interest. Lavoie and Seccarecia (2001) point out that the equations on page 135 of John Maynard Keynes "still incorporate the basic element of a loanable approach" (Lavoie and Seccarecia 2001). If one looks at the equations, they try to introduce dynamics in the argument by showing how planned investment can be funded. Minsky never stated that exante (planned) saving can finance investment — this possibility is absent in the book. If past savings are not enough, the only way to fund investment is to increase the money supply.

\section{FRAGILITY, INSTABILITY AND CRISIS}

The concepts of "financial fragility", "financial instability", and "financial crisis" have been widely used by Minsky and, sometimes, he has been accused of not giving a precise definition of what he meant (Goldsmith 1982). However, as he developed his theory, the definition became more precise. In the early work, there is no clear difference between fragility and instability.

The simplest and boldest way to qualify financial fragility is too associate it with overindebtedness (Minsky 1992; Fisher 1933). The concept of "overindebtedness"” is, however, relative to a "normal" indebtedness and so related to the notion of "optimal" financial structure which has already been rejected. There is no "true" or a priori optimal financial structure. It all depends on the conventions prevailing in the economic system and these conventions may lead to the implementation of economic activities that may make this optimality a reality.

One, then, needs to be more precise on what is meant by "fragility". One way to do so would be to define it by its antonym, namely "robustness". The robustness/fragility of the economy is, then, defined in the following way: 
The place of an economy on a financial robustness-fragility scale is determined by 1) the weight of hedge, speculative, and Ponzi finance units in the economy; 2) the willingness and ability of the authorities to refinance units at concessionary terms when current market rates transform units into Ponzi units; and 3) the in-place power of the authorities to sustain aggregate profits (cash flows to business) and aggregate wages when current market rates turn a large number of units into Ponzi financing units and when the flow of profits and wages could slow down. (Minsky 1993b)

The fragility/robustness of the economy is, thus, related to the structure of financial positions of private economic units and to the existence of what Minsky called "built-in stabilizers" (Minsky 1964a) - both endogenous and exogenous factors affect the domain of stability of the economy (Minsky 1972b). These endogenous factors are related to the classification between hedge, speculative, and Ponzi finance. Thus, in a robust financial system, "it takes large changes and there are only a few channels by which financial instability can be induced" (Minsky 1975b). The exogenous factors are related, not only to the lender of last resort intervention or the countercyclical fiscal policy, but also to a whole range of financial institutions and practices that limit the development of the possibility of instability and the financial weakening of the system (loan officers, existence of specialists, amortized mortgages, transfers) (Minsky 1963a, 1964a, 1981, 1984b, 1986a). In the end, therefore, fragility can be defined as the propensity of an economic system to generate financial instability. In a fragile financial system, even "a 'slight disturbance' in money flow" (Minsky 1964a) can generate financial instability because of the high articulation between cash inflows and cash outflows.

The problem becomes to define financial instability, which links the effect of financial fragility to the non-financial side of the economy. The best way to comprehend this notion is to start with the definition of macroeconomic stability given by Minsky.

Stability, in the macroeconomic sense, means that a close approximation to full employment at stable prices can be achieved and sustained by market processes. (Minsky 1981)

A market system is, therefore, financially unstable when it does not promote full employment and price stability. This shows that it is important to differentiate between "upward instability" and "downward instability" - the former being the cause of the latter (Minsky 1969a, 1980b). Clearly, a more fragile financial system is more prone to be unstable. In terms of upward instability this is so because a fragile financial system promotes inflation by increasing the cost 
of production and by the incorporation in expectations of a higher price level (Minsky 1975a). The first cause of inflation can be cured by decreasing interest rates, but the correction of expectations is harder to do, both because it is harder to change the mind of people and because these expectations sustain a level of indebtedness. Therefore, a "fragile financial system is particularly conductive to accelerated inflation” (Minsky 1975a). In terms of downward instability, a fragile system is more unstable because it promotes the emergence debt-deflation processes. In this case:

Financial instability, with respect to a given extent of financial distress exists whenever financial distress of this given extent or greater results in a financial crisis. The extent of financial distress refers to the number and distribution of the units that are in financial distress. If the extent of financial distress is below the critical level, then the endogenous phenomena by which one unit in distress affects other units will not lead to a financial crisis. If the extent of financial distress is above the critical level, then no further outside shocks are necessary for the financial system to generate a financial crisis. (Minsky 1964a)

The downward instability, therefore, depends on "the importance of uninterrupted flow of receipts" (Minsky 1972b) and the possibility of systemic risk. In case of high instability, the effects on the economy are important. ${ }^{15}$ This downward instability is promoted by several factors: the growth of short-term position-making instruments, a tighter central-bank policy, a tighter fiscal policy, and the increase in layering and possible "domino effect" (Minsky 1986a). In the end, therefore, the financial instability of an economic system is related to the propensity of financial fragility to have effects on non-financial variables.

Financial instability occurs when disturbances in an economy's financial structure- such as a stock market crash, major bank failure, or nonpayment of foreign debt obligations - affect the level of real activity in that economy. (Pollin and Dymski 1994)

Finally, a financial crisis characterizes a situation of widespread financial distress in the economy. If this distress manifests itself by a liquidation of some assets, then there is a large

\footnotetext{
15 A primitive version of this downward financial instability can be found in early Minsky’s articles (Minsky 1957b, 1959, 1965a). In this case, investment is affected by a financial accelerator that depends on the financial fragility of firms (represented by the equity and liquidity ratios). Later, this was replaced by the $P_{I d} / P_{I}$ framework, which, contrary to the previous articles, does not ignore uncertainty (Minsky 1972b).
} 
drop in the price of those assets. A financial crisis may have real effects and promote a debtdeflation process depending on how unstable the economic system is.

All this has one important implication for the modeling of Minsky's framework. His analysis does not rely on the emergence of "shocks" to generate financial crises. Normal variations in cash inflows, or delays in the receptions of the inflows, may lead to a financial crisis in a fragile financial system. This does not exclude, of course, the possibility of a shock, like an increase (expected or not) of the central-bank policy rates, an increase in the cost of raw materials, or any other external factors. The point is, that even without those shocks, a financial crisis and an economic recession can be generated because the turning point is endogenously determined (Minsky 1982a). Therefore, the immediate cause of a financial crisis does not matter. The forces at work that led to the crisis started to operate a long time before the factors triggering the occurrence of the crisis.

\section{THE ROLE OF THE BOOM PERIOD}

The analysis of Minsky's theoretical framework process would not be complete without referring the boom period. The latter is a short-term phenomenon that "lives a precarious life" (Minsky 1975a), during which the economy is close to full employment and is led by a euphoric optimism. For Minsky, even if this period is very short, it is essential:

In this interpretation the boom is critical; it builds an ever-more-demanding liability structure on the base of a cash-flow foundation consisting of prospective yields of capital assets, which are, because of technology and the limited ability to squeeze workers' real wages, at best constrained ultimately to grow at a steady rate in real terms. The debt base, which grows at an accelerating rate during a boom, is not so constrained. (Minsky 1975a)

The idea behind the boom period is, therefore, that the cash inflows from operation and contracts cannot grow as fast as the commitments on balance sheets without generating inflation. As shown above, aggregate prices depend on the average productivity of labor and are a decreasing function of the level of output given technology. Therefore, at full employment, a free market economy will be subject to an inflation barrier due to real constraints that can only be removed by technological progress, by better training of workers, or by squeezing the nominal wage of 
workers. This inflationary pressure will build up in the financial contracts, and the economy will become more sensitive to the realization of price expectations, which will lead to a crisis when the expectations will not be realized.

In an economy with a big government that applies an Employer of Last Resort program, an income policy, and follows a functional finance approach, the inflationary pressure would be dampened. In this case, aggregate profit can only increase with improvements in the productive capacity of the economy because additional total spending would be authorized only when it does not generate inflation. In an economy in which the preceding type of government does not exist, the inflationary pressure would lead to a large tightening of fiscal and monetary policies, ${ }^{16}$ which would squeeze profit on both sides (demand and financial cost) and could precipitate a crisis.

The importance of the real constraints and productivity in the determination of profit is, therefore, not related to a neoclassical foundation of the nature of profit. It is related to the problem of "inflation barrier" which, if unchecked, leads to a deep crisis, and, if checked correctly, imposes a constraint on aggregate spending so that the latter grows only with the improvement in the capacity of production.

Another factor that enters into consideration during the boom is the emergence of widespread unproductive economic activities that are funded externally like "corporate maneuverings, takeovers, mergers and conglomerate expansions that characterize the boom" (Minsky 1975a). Also during this period, "households will become more willing to use more debt to own shares, bankers will be more willing to finance such 'margin' purchase of shares" (Minsky 1975a). This kind of activity increases the amount of cash commitments without financing or funding any actual or potential increase in aggregate income. The capacity to meet cash commitments rests on an expected bonanza, via realized capital gains.

If the boom matters, however, it can only explain the acceleration of the financial weakening of the economy but cannot explain the progressive weakening of financial positions. As Minsky recognized:

\footnotetext{
${ }^{16}$ In today's world, this occurs actually far before full employment because of the obsession with low inflation, even when there is no sign of inflation at all.
} 
Even though a prolonged expansion, dominated by private demand, will bring about a transformation of portfolios and changes in asset structures conductive to financial crises, the transformations in portfolios that take place under euphoric conditions sharply accentuate such trends. [...] Thus, the theory of financial stability takes into account two aspects of the behavior of capitalist economy. The first is the evolution of the financial structure over a prolonged expansion [...]. The second consists of the financial impacts over a short period due to the existence of highly optimistic euphoric economy; the euphoric economy is a natural consequence of the economy doing well over a prolonged period. (Minsky 1972b, italics added)

A capitalist economy will become fragile in the first place because of the way borrowing and lending activities are conducted in an uncertain world - margins of safety are determined by a convention and maturity mismatch. The boom, or euphoric period, only precipitates the turning point that would occur anyway, unless economic growth was driven by governmental expenditures. This last point is very important:

During a protracted expansion dominated by household and business deficits the ratio of household and business financial commitments to income rises, whereas in an expansion dominated by government deficits the ratio of private commitments to income decreases. (Minsky 1963b)

Economic growth, therefore, will not generate a weakening of financial positions of private units if it is based on government spending that injects safe assets in the balance sheet of private units. $^{17}$

All this has important implications for the modeling of Minsky's theoretical framework, especially for the dynamics of the system. A non-inflationary level of income is constrained, in a full employment situation, to grow only at a rate determined by the growth in the productivity of labor and capital. This is not explained by a real origin of the rate or level of profit. On the other side, the growth of financial commitments is potentially unlimited and the central bank has the important task to limit this growth.

\footnotetext{
${ }^{17}$ More generally, when doing econometric studies, it is important to know which sector, or which part of a sector, is leading economic activity because it is in this one that the forces underlying the Financial Instability Hypothesis will emerge.
} 


\section{FINANCIAL STRUCTURE, INFLATION, EMPLOYMENT AND POLICY}

One last important point of Minsky's theory concerns the impact of all the preceding on inflation and employment, that is, their origins and how they can be prevented. At the theoretical level, there are two important points. The first point, in the tradition of Keynes, is that full employment equilibrium (let alone stable full employment equilibrium) is not the natural outcome of a free market economy. One of the main roles of the government is, thus, to promote full employment. The second point is that inflation does not necessarily have monetary origins.

Monetary abundance and monetary growth are not, in and of themselves, sufficient cause of rapid inflation. (Minsky 1983b)

Additional conditions are necessary and among them are a complex financial structure, a fiscal policy that is irresponsible (failed to use taxes to protect the value of its IOUs), and policy-goals that are oriented toward growth rather than full-employment (Minsky 1975a, 1983b). This last cause is important because it shows that Minsky divorces the full employment and economic growth goals - they are independent goals.

In front of the structural flaws of the capitalist system, authorities can choose among three solutions (Minsky 1962): let the debt-deflation process go, stagflation, or full employment policy. The last two prevent deflation, but stagflation, promoted by growth-oriented policies, is not ideal. Therefore, at the practical level, the role of the government is not to promote growth:

The maintenance of a robust financial structure is a precondition for effective anti-inflation and full employment policies without a need to hazard deep depressions. (Minsky 1978)

From our theoretical analysis it is evident that policy should aim at achieving and sustaining a robust financial structure. [...] The policy problem is to develop a strategy for full employment that does not lead to instability, inflation, and unemployment. (Minsky 1986a)

Davidson (1978) noted that the promotion of hedge financing may not be good because it may decrease aggregate demand or may decrease its growth. Pollin and Dymski (1994) have shown 
that a big government era ${ }^{18}$ leads to smoother but slower economic growth. Minsky is conscious of that, but he puts forward several reasons why this is the best policy. First, a strong financial structure increases the effectiveness of monetary and fiscal policy by limiting the moral hazard generated by the existence of a floor on profit and asset prices (Minsky 1972b, 1985). Indeed, in a strong financial structure, it is possible to have "a depression without a depression" (Minsky $1975,1975 d$ ), that is to say, the good financial effects of a depression (increase in prudence, increase in the liquidity of portfolios, decrease in leveraging) without the negative effects (massive bankruptcies, high unemployment, wastage). On the contrary, in a fragile financial structure, the floors have to be put higher ("premature" lender of last resort intervention and countercyclical fiscal policy) and this may prevent the restoration of sound financial practices (Minsky 1963b, 1972b, 1977b, 1983b). Second, full employment policy is, in a capitalist economy, the best way to fight poverty by providing a guaranteed access to a job (Minsky 1965b, 1965c, 1966; Davidson 1968; Bell and Wray 2004). ${ }^{19}$ Third, inflation is far more difficult to deal with in a fragile environment. Indeed, when inflation expectations are incorporated into the expectations of cash inflows, and so the normal financial structure, a decrease in inflation may promote financial instability (Minsky 1975a). In addition, the "paradox of monetary policy" is that lender of last resort is inflationary (Minsky 1975b). This does not mean that it will automatically generate inflation but, in a fragile environment, monetary inflation has more chance to occur. Finally, as stated earlier, employment and growth should, for Minsky, be unrelated.

In the end, therefore, a stabilization policy, coupled with an employer of last resort program (Minsky 1983a, 1986a), an income policy, ${ }^{20}$ and a socialization of investments related to private needs is the best policy package today (Minsky 1983a, 1986a). The stabilization policy includes both containment of financial crisis and guidance of the financial practices. Concerning the central bank, it should let the financial market innovate and experiment, but should set the

\footnotetext{
${ }^{18}$ Past and current experiences of big government in developed capitalist economies have not been implemented in a way consistent with Minsky's proposal: they have relied on fine-tuning and growth. (Minsky 1975a)

${ }^{19}$ Dymski and Pollin (1992) argue that distributive questions are of secondary importance in Minsky's approach: "such ideas are mere asides in his overall framework" (Dymski and Pollin 1992). This is not the case. Very early in his career (mid 1960s), Minsky pushed for a more equitable capitalism and, for him, the best way to do so is to promote stable full employment. The latter needs a stable financial system.

${ }^{20}$ The employer of last resort, by fixing the minimum wage rate, will already contribute to the stabilization of wage (Minsky 1983a). An income policy may improve this control and may also complement it on the mark-up side (Davidson 1968).
} 
permissible financial techniques by accepting them or not in its refinancing operations, or by making it more costly to use a financial technique (Minsky 1967b, 1980d, 1982b; Wray 1992; Kregel 1992):

The Federal Reserve could expedite the growth of the commercial paper market by making dealers in such paper eligible for accommodation at the discount window. It could create a barrier to these developments by requiring commercial banks to hold reserves against unused portions of contractual lines of credit, thus making it more expensive to use the banking system as a 'residual' lender. (Minsky 1969b)

If it disapproves of certain financial developments and the latter are in trouble, a central bank should let the crisis go while protecting other markets against adverse effects. A central bank has, thus, a capacity to affect the direction that the financial system takes, especially when the financial system is robust. In addition, a central bank can affect the profitability of some financial practices, and so can guide the activities of financial institutions by putting limits on bank equity, controlling usages, supervising and regulating financial institutions, and legitimating some financial instruments and disapproving others via its refinancing policy (which optimally should go through the discount window) (Minsky 1967b, 1975c, 1986a; Campbell and Minsky 1987; Kregel 1992; Shull 1993; Phillips 1997). In period of financial fragility, the role of a central bank is limited to containment and it cannot guide the system, but merely validates existing innovations and financial practices. In period of financial fragility, the role of fiscal policy is also containment. The containment and guidance strategies of public authorities affect the liquidity preference of the suppliers of funds and, so, their behaviors. In the end, the goal of these policies is to increase the stability of the system, especially when full employment is reached, by making speculative financing less attractive.

This stabilization policy is, however, limited in its effectiveness because a stabilization policy has "pitfalls" (Minsky 1983b). Successful policies change the responses to policy; big government has inflationary tendencies and stabilization of some variables destabilize other dimensions. Here again, at the policy level, we find the dialectic approach that is present in all 
Minsky's analyses. ${ }^{21}$ Thus, regulation has always to adapt itself; there are no definitive solutions or rules that guarantee stability.

There is no final solution to the problems of organizing economic life. (Minsky 1975a)

The only universal rule for Federal Reserve policy is that it cannot be dictated by any universal rule. (Minsky 1977c)

Economic policy cannot be reduced to a set of invariable rules. (Minsky 1989b)

Psychological factors (individual factors), conventional valuation (social factors), profit seeking behaviors, and competition for monetary accumulation will always have the tendency to promote instability, and the authorities have to take this into account in their policy (Papadimitriou and Wray 1997).

All this is important for the modeling because it gives a framework to test different policy alternatives (no policy, fine-tuning, stabilization) and compares their effects on the economic system. The basic trend should be that a "no policy" position leads to prolonged downward instability, fine-tuning leads to high upward instability and damped downward instability, and that stabilization should limit both upward and downward instability and promote employment but also lower economic growth. The preceding also provides a way to judge the effectiveness of build-in stabilizers: built-in stabilizers can be "too effective" (Minsky 1972b). Indeed, effective built-in stabilizers stabilize the economic system and lead to a downward revision of expectations toward more conservative financial criteria. If the second criteria to judge the effectiveness of stabilizers is not respected, the economy will start to expend before it has reached robustness, and long-term stabilization will be sacrificed for the sake of short-term stability (Minsky 1975d). In the end, therefore, a stable financial structure is needed for effective stabilization policy, and a good stabilization policy is needed for a stable financial structure.

\footnotetext{
${ }^{21}$ Talking about policy in Minsky's framework, Pollin and Dymski also note that: "Minsky's framework, in short, is permeated with dialectical tension." (Pollin and Dymski 1994).
} 


\section{CONCLUSION}

The modeling of Minsky's theory is very demanding and cannot be adequately done by using the traditional tools and methods of the neoclassical analysis: real values are not the basis of economic decisions, financing and funding matter, conventional behavior is rational and needs to be systematically modeled, money-things are debt instruments, endogeneity and elasticity of money are different, the cash box condition is central, the cost of external funds cannot be reduced to interest payments, profit is based on the scarcity of capital assets and not on the productivity of capital assets, etc. The Minskyan framework does not assume that people are irrational, or that money is exogenous and rejects the relevance of asymmetry of information and the loanable funds theory. The foundations of the dynamics of the capitalist system are set in the way economic activities are financed and funded, and on the psychological, sociological and macroeconomic elements playing on the decision process.

In addition, the modeling implies doing a good analysis of the institutional context of the economic system modeled; different capitalist systems have different financial and productive systems and so different ways to finance and fund their economic activities. This is important to grab because the structure of balance sheets (both on- and off-balance sheet components) determine the cash flows and so the liquidity of economic agents. Depending on the financial structure, the channels of financial weakening, if they are active, will be different, and if they are inactive they may be triggered differently. This last point is important and has not been treated in the paper — the "financial instability hypothesis" concerns the dynamics of the Minskyan models induced by the essential characteristics developed above. These dynamics are complex and will be treated in another paper.

This theory also has clear policy implications. First, a big government is necessary "if freedom to innovate and to finance is the rule" (Minsky 1993b). If one adopts a free market economy, one must also adopt a big government - they are necessary complement. Second, full employment policy and financial robustness policy are central policy goals - they promote the social equity and financial stability that a market system does not provide. Third, each public institution should be exclusively assigned to the goal it can deal with most effectively - the central bank should deal exclusively with financial matters, the Treasury should help to maintain 
a stable (i.e., non-inflationary) full employment level, and other institutions have to be created to promote full employment and price stability. Fiscal and monetary policies should discard finetuning, as well as growth oriented policies, as both lead to stagflation. 


\section{REFERENCES}

Bell, S. 2001. "The role of the state and the hierarchy of money." Cambridge Journal of Economics 25 (2): 149-163.

Bell, S. and L. R. Wray. 2004. "The 'War on Poverty' after 40 years: A Minskyian assessment." Jerome Levy Economics Institute of Bard College, Working Paper 404.

Bernanke, B. S. 1983. "Nonmonetary effects of the financial crisis in the propagation of the Great Depression." American Economic Review 73 (3): 257-276.

Benston, G. J. and G. G. Kaufman. 1995. "Is the banking and payments system fragile?" Journal of Financial Services Research 9 (3-4): 209-240. Reprinted in Benink, H. A. (ed.) Coping with Financial Fragility and Systemic Risk. Boston: Ernst \& Young.

Boyer-Xambeu, Marie-Thérèse, Ghislain Deleplace, and Lucien Gillard. 1994. Private Money and Public Currencies. New York: M.E. Sharpe.

Brossard, O. 1998. "L'instabilité financière selon Minsky: L'incertitude et la liquidité au fondement du cycle?" Revue Economique 49 (2): 407-435.

. 2001. D’un krach à l'autre: Instabilité et régulation des économies monétaires. Paris: Editions Grasset \& Fasquelle/Le Monde de l'éducation.

Campbell, C. and H. P. Minsky. 1987. "How to get off the back of a tiger or, do initial conditions constrain deposit insurance reform?" In Merging Commercial and Investment Banking (Proceedings of a Conference on Bank Structure and Competition). Chicago: Federal Reserve Bank of Chicago.

Caskey, J. and S. Fazzari. 1986. "Macroeconomics and credit markets." Journal of Economic Issues 20 (2): 421-429.

Chick, V. 1986. "The evolution of the banking system and the theory of saving, investment and interest." Economies et Sociétés 20 (8-9), MP 3: 111-126. Reprinted in Arestis, P. and S.C. Dow (eds.) On Money, Method and Keynes: Selected Essays. London: Macmillan.

Crotty, J. R. 1994. "Are Keynesian uncertainty and macrotheory compatible? Conventional decision making, institutional structure, and conditional stability in Keynesian macromodels.” In Dymski, G. and R. Pollin (eds.) New Perspectives in Monetary Macroeconomics. Ann Arbor: University of Michigan Press.

Davidson, P. 1968. "The role of monetary policy in the overall economic policy." Reprinted in Davidson, L. (ed.) The Collected Writings of Paul Davidson, vol. 1. New York: New York University Press. 
. 1978. Money and the Real World. London: Macmillan.

2002. Financial Markets, Money, and the Real World. Northampton: Edward Elgar.

Dunn, S. P. 2001. "Bounded rationality is not fundamental uncertainty: a Post Keynesian perspective." Journal of Post Keynesian Economics 23 (4): 567-589.

Dymski, G. 1994. "Asymmetric information, uncertainty, and financial structure: 'New' versus 'Post-' Keynesian microfoundations." In Dymski, G. and R. Pollin (eds.) New Perspectives in Monetary Macroeconomics. Ann Arbor: University of Michigan Press.

Dymski, G. and R. Pollin. 1992. "Hyman Minsky as hedgehog: The power of the Wall Street paradigm.” In Fazzari, S. and D. B. Papadimitriou (eds.) Financial Conditions and Macroeconomic Performance. Armonk, N.Y.: M. E. Sharpe.

Fazzari, S. 1992. "Keynesian theories of investment and finance: Neo, Post, and New." In Fazzari, S. and D. B. Papadimitriou (eds.) Financial Conditions and Macroeconomic Performance. New York: M. E. Sharpe.

Fazzari, S. and H. P. Minsky. 1984. "Domestic monetary policy: If not Monetarism, what?" Journal of Economic Issues 18 (1): 101-116.

Ferri, P. and H. P. Minsky. 1989. "The breakdown of the IS-LM synthesis: Implication for PostKeynesian economic theory." Review of Political Economy 1 (2): 123-143.

Fisher, I. 1933. "The debt-deflation theory of the Great Depression.” Econometrica 1 (4): 337 357.

Friedman, M. 1969. “The optimal quantity of money.” In Friedman, M. (ed.) The Optimal Quantity of Money. Chicago: Aldine.

Frank, R. and W. Semmler. 1989. "Debt-financing of firms, stability, and cycles in a dynamical macroeconomic growth model." In Semmler, W. (ed.) Financial Dynamics and Business Cycles. New York: M. E. Sharpe.

Goldsmith, R. W. 1982. “Comment.” In Kindleberger, C. P. and J.-P. Laffargue (eds.) Financial Crises: Theory, History, Policy. Cambridge: Cambridge University Press.

Goldstein, D. 1995. "Uncertainty, competition, and speculative finance in the eighties." Journal of Economic Issues 24 (3): 719-746.

Harvey, J. 1998. "Heuristic judgment theory” Journal of Economic Issues 32 (1): 47-64

Innes, A. M. 1913. "What is money?" Banking Law Journal, 30 (5): 377-408. Reprinted in Wray, L. R. (ed.), Credit and State Theories of Money. Northampton: Edward Elgar. 
. 1914. "Credit theory of money?" Banking Law Journal 31 (2): 151-168. Reprinted in Wray, L. R. (ed.), Credit and State Theories of Money. Northampton: Edward Elgar.

Isenberg, D. L. 1988. "Is there a case for Minsky's financial fragility hypothesis in the 1920s?" Journal of Economic Issues 27 (4): 1045-1069.

. 1994. "Financial fragility and the Great Depression: New evidence on credit growth in the 1920s." In Dymski, G. and R. Pollin (eds.) New Perspectives in Monetary Macroeconomics. Ann Arbor: University of Michigan Press.

Kahn, R. F. 1931. "The relation of home investment to unemployment.” Economic Journal, 41 (162): 173-198. Reprinted in Kahn, R. F. (ed.), Essays on Employment and Growth. Cambridge: Cambridge University Press.

Kahneman, D. and A. Tversky. 1973. "On the psychology of prediction." Psychological Review 80(4): 237-251.

Kalecki, M. 1971. "The determinants of profits." In Kalecki, M. (ed.) Selected Essays on the Dynamics of the Capitalist Economy. Cambridge: Cambridge University Press.

Keynes, J. M. 1933. “A monetary theory of production.” Reprinted in Moggridge D. (ed.), The Collected Writings of John Maynard Keynes, vol. 13. London: Macmillan.

. 1936. The General Theory of Employment, Interest, and Money. New York: Harcourt Brace. Reprinted in Moggridge D. (ed.), The Collected Writings of John Maynard Keynes, vol. 7. London: Macmillan.

Kregel, J. A. 1976. "Economic methodology in the face of uncertainty: the modeling methods of Keynes and the Post-Keynesians." Economic Journal 85 (342): 209-225.

. 1992. "Minsky's 'two price' theory of financial instability and monetary policy: Discounting vs. open market intervention." In Fazzari, S. and D. Papadimitriou (eds.) Financial Conditions and Macroeconomic Performance. Armonk, N.Y.: M. E. Sharpe.

. 1997. "Margins of safety and weight of the argument in generating financial crisis." Journal of Economic Issues 31 (2): 543-548.

Lavoie, M. 1983. "Loi de Minsky et loi d'entropie." Economie Appliquée 36 (2): 287-331.

. 1986. "Minsky's law or the theorem of systemic financial fragility." Studi

Economici 41 (29): 3-28.

. 1987. "Monnaie et production: une synthèse de la théorie du circuit." Economies et Sociétés 20 (9) MP 4: 65-101.

. 1992. Foundations of Post-Keynesian Economic Analysis. Aldershot: Edward Elgar. 
. 1996. "Horizontalism, structuralism, liquidity preference and the principle of increasing risk." Scottish Journal of Political Economy 43 (3): 275-300.

. 1997. "Loanable funds, endogenous money, and Minsky's financial fragility hypothesis." In Cohen, A. J., H. Hagemann, and J. Smithin (eds.) Money, Financial Institutions, and Macroeconomics. Boston: Kluwer Nijhoff.

Lavoie, M. and Seccarecia, M. 2001. “Minsky’s financial fragility hypothesis: A missing macroeconomic link?" In Bellofiore R. and P. Ferri (eds.) Financial Fragility and Investment in the Capitalist Economy, volume 2. Cheltenham: Edward Elgar.

Meiselman, D. 1967. "Strotz and Minsky on monetary variables and aggregate demand." In Horrwich, G. (ed.) Monetary Process and Policy. Homewood: Richard D. Irwin, INC.

Minsky, H. P. 1957a. “Central banking and money market changes.” Quarterly Journal of Economics 71 (2): 171-187.

. 1957b. "Monetary systems and accelerator models." American Economic Review 47 (6): $859-883$.

. 1959. "A linear model of cyclical growth." Review of Economics and Statistics 41 (2), Part 1: 133-145.

. 1962. "Financial constraints upon decisions, an aggregate view." Proceedings of the Business and Economic Statistics Section. Washington D. C.: American Statistical Association.

. 1963a. “Can 'it' happen again?” In Carson, D. (ed.) Banking and Monetary Studies, Homewood (Illinois): Richard D. Irwin. Reprinted in Minsky, H. P. (ed.) Can 'It' Happen Again?. New York: M. E. Sharpe.

. 1963b. "Financial institutions and monetary policy—discussion." American Economic Review 53 (2): 401-412.

. 1964a. "Financial crisis, financial system and the performance of the economy." In Private Capital Markets, ed. Commission on Money and Credit. Englewood Cliffs: Prentice-Hall.

. 1964b. "Long waves in financial relations: Financial factors in the more severe depression.” American Economic Review 54 (3): 324-335.

. 1965a. "The integration of simple growth and cycle models." In Brennan, M. J. (ed.) Patterns of Market Behavior, New England: University Press of New England. Reprinted in Minsky, H. P. (ed.) Can 'It’ Happen Again?. New York: M. E. Sharpe. 
. 1965b. "The role of employment policy." In Gordon, M. S. (ed.) Poverty in

America. San Francisco: Chandler Publishing Company.

. 1965c. "Poverty: The 'aggregate demand' solution and other non-welfare approaches." Report MR-41, Institute of Government and Public Affairs. Los Angeles: University of California.

. 1966. "Tight full employment: Let's heat up the economy.” In Miller, H. P. (ed.)

Poverty: American Style. Belmont: Wadsworth Publishing Company.

. 1967a. "Money, other financial variables, and aggregate demand in the short run." In Horwich, G. (ed.) Monetary Process and Policy. Homewood, Illinois: Richard D. Irwin.

. 1967b. "Financial intermediation in the money and capital markets." In Pontecorvo, G., R. P. Shay, and A. G. Hart (eds.) Issues in Banking and Monetary Analysis. New York: Holt, Rinehart and Winston, Inc.

. 1969a. "Private sector asset management and the effectiveness of monetary policy: Theory and practice." Journal of Finance 24 (2): 223-238.

. 1969b. "The new uses of monetary power." Nebraska Journal of Economics and Business 8 (2). Reprinted in Minsky, H. P. (ed.) Can 'It' Happen Again?. New York: M. E. Sharpe.

. 1969c. "Financial model building and federal reserve policy- Discussion." Journal of Finance 24 (2): 291-297.

. 1971. "Notes on user cost." Mimeograph.

. 1972a. “An exposition of a Keynesian theory of investment.” In Szegö and Shell (eds.) Mathematical Methods in Investment and Finance, North-Holland. Reprinted in Minsky, H. P. (ed.) Can 'It' Happen Again?. New York: M. E. Sharpe.

. 1972b. "Financial instability revisited: The economics of disaster." In Reappraisal of the Federal Reserve Discount Mechanism, volume 3, ed. Board of Governors. Washington D. C.: Board of Governors.

.1972c. "An evaluation of recent monetary policy." Nebraska Journal of Economics and Business 11 (4): 37-56.

. 1974. "The modeling of financial instability: An introduction." Modeling and Simulation 5, Part 1, 267-272. Reprinted in Compendium of Major Issues in Bank Regulation. Washington D. C.: Government Printing Office, 1975.

. 1975a. John Maynard Keynes. Cambridge: Cambridge University Press. 
. 1975b. "Financial instability, the current dilemma, and the structure of banking and finance." In Compendium of Major Issues in Bank Regulation. Washington D. C.: U.S. Government Printing Office.

. 1975c. "Suggestion for a cash flow-oriented bank examination." Proceedings of a Conference on Bank Structure and Competition. Chicago: Federal Reserve Bank of Chicago.

. 1975d. "Financial resources in a fragile financial environment." Challenge JulyAugust: 6-13.

. 1977a. "Banking and a fragile financial environment." Journal of Portfolio Management Summer: 16-22.

. 1977b. "The financial instability: An interpretation of Keynes and an alternative to 'standard' theory." Nebraska Journal of Economics and Business 16 (1): 5-16. Reprinted in Minsky, H. P. (ed.) Can 'It’ Happen Again?. New York: M. E. Sharpe.

. 1977c. "A theory of systemic fragility." In Altman, E. I. and A. W. Sametz (eds.) Financial Crises. New York: Wiley.

. 1978. "The financial instability hypothesis: A restatement." Thames Papers in Political Economy, Autumn. Reprinted in Arestis, P. and T. Skouras (eds.) Post Keynesian Economic Theory. New York: M. E. Sharpe.

. 1979. "Financial interrelation and the balance of payments, and the dollar crisis." In Aronson, J. D. (ed.) Debt and the Less Developed Countries. Boulder: Westview Press.

. 1980a. "Finance and profit: The changing nature of American business cycle." In Joint Economic Committee (ed.) The Business Cycle and Public Policy, 1929-1980. Washington D. C.: U.S. Government Printing Office. Reprinted in Minsky, H. P. (ed.) Can 'It' Happen Again?. New York: M. E. Sharpe.

. 1980b. "Capitalist financial processes and the instability of capitalism." Journal of Economic Issues 14 (2): 505-523.

. 1981. "Financial markets and economic instability, 1965-1980." Nebraska Journal of Economics and Business 20 (4): 5-17.

. 1982a. "The financial-instability hypothesis: Capitalist process and the behavior of the economy." In Kindleberger, C. P. and J.-P. Lafargue (eds.) Financial Crises. New York: Cambridge University Press.

. 1982b. "Can 'It' happen again? A Reprise.” Challenge July-August: 5-13. 
. 1983a. "Institutional roots of American inflation." In Schmukler, N. and E. Marcus (eds.) Inflation Through the Ages: Economic, Social, Psychological and Historical Aspects. New York: Brooklyn College Press.

. 1983b. "Pitfalls due to financial fragility." In Weintraub, S. and M. Goodstein (eds.) Reaganomics in the Stagflation Economy. Philadelphia: University of Pennsylvania Press.

. 1984a. "Financial innovations and financial instability: Observations and theory." In Federal Reserve Bank of St. Louis (ed.) Financial Innovations. Boston: Kluwer-Nijhoff.

. 1984b. "Banking and industry between the two wars: The United States." Journal of European Economic History 13 (Special Issue): 235-272.

. 1985. "Money and the lender of last resort." Challenge March-April: 12-18.

. 1986a. Stabilizing an Unstable Economy. New Haven: Yale University Press.

. 1986b. "Global consequences of financial deregulation." In The Marcus Wallenberg Papers on International Finance 2 (1): 1-19. Washington D. C.: International Law Institute and School of Foreign Service, Georgetown University.

. 1986c. "An introduction to Post-Keynesian economics." Economic Forum 15, Winter: 1-13.

. 1986d. "The evolution of the financial institutions and the performance of the economy.” Journal of Economic Issues 20 (2) June: 345-353.

. 1989a. "Financial crises and the evolution of capitalism: The crash of ' 87 -what does it mean?"' In Gottdiener, M. and N. Komninos (eds.) Capitalist Development and Crisis Theory: Accumulation, Regulation and Spatial Restructuring. New York: St Martin's Press.

. 1989b. "The macroeconomic safety net: Does it need to be improved?" In Gray, P. (ed.) Research in International Business and Finance Volume 7. Greenwich (Connecticut): JAI Press.

. 1989c. "Comments and discussions." Brookings Papers on Economic Activity 2: 173-189.

. 1989d. "Financial structures: Indebtedness and credit." In Barrère, A. (ed.) Money Credit and Prices in a Keynesian Perspective. New York: St. Martin's Press.

. 1990a. "Sraffa and Keynes: Effective demand in the long run." In Bharadwaj, K. and B. Schefold (eds.) Essays in Piero Sraffa. London: Unwin Hyman. 
. 1990b. "Money manager capitalism, fiscal independence and international monetary reconstruction.” In Szabó-Pelsőczi, M. (ed.) The Future of The Global Economic and Monetary System. Budapest: Institute for World Economics of the Hungarian Academy of Sciences.

. 1991a. "The endogeneity of money." In Nell, E. J. and W. Semmler (eds.) Nicholas Kaldor and Mainstream Economics. New York: St. Martin's Press.

. 1991b. "The instability hypothesis: A clarification.” In Feldstein, M. (ed.) The Risk of Economic Crisis. Chicago: University of Chicago Press.

. 1991c. "Financial crises: Systemic or idiosyncratic", The Jerome Levy Economics Institute of Bard College, Working Paper 51.

. 1992. "The capital development of the economy and the structure of financial institutions." The Jerome Levy Economics Institute of Bard College, Working Paper 72.

. 1993a. "Schumpeter and finance." In Biasco, S., A. Roncaglia, and M. Salvati (eds.) Market and Institutions in Economic Development. New York: St. Martin's Press.

. 1993b. "On the non-neutrality of money." Federal Reserve Bank of New York Quarterly Review 18 (1): 77-82.

. 1994. "Financial instability and the decline (?) of banking public policy implications." In Proceedings of a Conference on Bank Structure and Competition. Chicago: Federal Reserve Bank of Chicago.

. 1996. "The essential characteristics of Post-Keynesian economics." In Deleplace, G. and E. J. Nell (ed.) Money in Motion. New York: St. Martin's Press.

Moore, B. J. 1996. "The money supply process: A historical reinterpretation." In Deleplace, G. and E. J. Nell (eds.) Money in Motion. London: Macmillan.

Mullineux, Andrew W. 1990. Business Cycles and Financial Crises. Ann Arbor: University of Michigan Press.

Papadimitriou, D. B. and L. R. Wray. 1997. “A tribute to Hyman P. Minsky.” Journal of Economic Issues 31 (2): 491-500.

Parguez, A. 1984. “La dynamique de la monnaie.” Economies et Sociétés 18 (4), MP1: 83-118. . 2003. "The pervasive saving constraint in Minsky's theory of crises and the dual profits hypothesis: Minsky as a Post-Keynesian Hayekian." In Rochon, L. P. and S. Rossi (eds.) Modern Theories of Money. Cheltenham: Edward Elgar. 
Pollin, R. and G. Dymski. 1994. "The costs and benefits of financial instability: Big government capitalism and the Minsky paradox." In Dymski, G. and R. Pollin (eds.) New Perspectives in Monetary Macroeconomics. Ann Arbor: University of Michigan Press.

Phillips, R. 1997. "Rethinking bank examinations: A Minsky approach.” Journal of Economic Issues 31 (2): 509-516.

Rochon, L. P. 2003a. "Money and endogenous money: Post-Keynesian and Circulation approaches". In Rochon, L.-P. and S. Rossi (eds.) Modern Theories of Money. Cheltenham: Edward Elgar

. 2003b. "Financial Instability Hypothesis." In King, J. E. (ed.) The Elgar Companion to Post Keynesian Economics. Northampton: Edward Elgar.

Sawyer, M. 1985. The Economics of Michal Kalecki. Armonk: M. E. Sharpe

Shiller, R. J. 1999. "Human behavior and the efficiency of the financial system." In Taylor, J. B. and M. Woodford (eds.) Handbook of Macroeconomics, vol. 1c. Amsterdam: NorthHolland. 2000. Irrational Exuberance. Princeton: Princeton University Press.

Shull, B. 1993. "The limits of prudential supervision.” The Jerome Levy Economics Institute of Bard College, Public Policy Brief No. 5.

Stanfield, J. R. and R. J. Phillips. 1991. "Economic power, financial instability, and the Cuomo report." Journal of Economic Issues 25 (2): 347-354.

Taylor, L. and S. O’Connell. 1985. “A Minsky crisis.” Quarterly Journal of Economics (100) Supplement: 871-885. Reprinted in Semmler, W. (ed.) Financial Dynamics and Business Cycles. New York: M. E. Sharpe.

Tversky, A. and D. Kahneman. 1974. "Judgment under uncertainty: Heuristic and bias.” Science 185 (27 September): 1124-1131.

Weintraub, S. 1978. Capitalism's Inflation and Unemployment Crisis. Reading, Massachusetts: Addison-Wesley.

Whalen, C. J. 1997. "Money-manager capitalism and the end of shared prosperity." Journal of Economic Issues 31 (2): 517-525.

Wojnilower, A. M. 1977. “L'envoi.” In Altman, E. I. and A. W. Sametz (eds.) Financial Crises. New York: Wiley. 
Wray, L. R. 1992. "Minsky's financial instability hypothesis and the endogeneity of money." In Fazzari, S. and D. B. Papadimitriou (eds.) Financial Conditions and Macroeconomic Performance. Armonk, N.Y.: M. E. Sharpe.

. 1992. "The 1966 financial crisis: financial instability or political economy?" Review of Political Economy 11 (4): 415-425.

. 1998. Understanding Modern Money. Vermont: Edward Elgar. 